\title{
국내·외 봉사활동간 파트너십 강화 방안
}

목 차

I. 서론

II. 자원봉사(volunteering)에 대한 이해: 자원봉사란 무엇인가?

III. 현대적 의미의 한국자원봉사의 발전과정 및 현황

1. 한국 자원봉사의 주요 발전 연혁

2. 한국 자원봉사 운영 현황 : 2014년도 자원봉사실태조사 분석 결과 중심으로

3. 자원봉사단체

4. 자원봉사센터

IV. 국내 자원봉사 활성화 노력

1. 정부의 노력

2. 2016-2018 한국자원봉사의 해 선포

3. 사회문제 해결로서의 자원봉사

4. 계층별 자원봉사

V. 아태지역 자원봉사

1. SDGs 실현을 위한 자원봉사

2. 자원봉사 인프라를 위한 역량 개발

3. 지역 청년들의 성장을 돕는 사례

VI. 국내봉사활동 운영 시사점과 해외 봉사활동과의 파트너십 강화를 위한 제언

1. 사람(people)

2. 프로그램(program)

3. 인프라 및 정책(Infrastructure \& Policy)

4. 한국의 시행착오가 주는 함의

참고문헌

1) 세계자원봉사협회(International Association for Volunteer Effort, IAVE) 아태지역 대표. 


\section{I. 서 론}

해외자원봉사활동은 국내의 봉사활동과 따로 존재하기가 어렵다. 한국에서의 자원봉사와 시민사회의 성숙이 이뤄질 때 해외자원봉사활동 수준도 높아질 것이기 때문이다. 해외자원봉 사활동에 나가는 사람들이 한국에서 의미 있는 자원봉사 경험을 충분히 하여 그 가치를 알고, 실천이 몸에 배인 경우 해외의 어느 상황에서도 그 가치와 실천이 드러날 것이기 때문이다.

그동안 우리나라에서는 올림픽 등 국가적 행사나 태안 기름유출 사고와 세월호 사건 등 재난재해 시 자원봉사가 큰 역할을 해왔다. 또한 복지 사각지대 해소에 중요한 파트너로서 역할을 해왔으며, 생태환경 보호, 교육격차 해소, 사회적 약자와 소외계층 대변 등 여러 크고 작은 사회문제 해결에 큰 역할을 해오고 있다. 이러한 자원봉사자의 힘을 인식하여 정부는 각 부처별로 자원봉사 활성화를 위한 정책(policy) 수립과 인프라(infrastructure) 구축을 해오 고 있다.

그 결과 자원봉사의 제도화 수준이 세계에서 가장 잘 되어 있는 나라 중 하나가 되었다. 그러나 기본적으로 생계 및 생활 유지로 인해 여유가 없어 자원봉사에 대한 적극적인 참여 의 어려움이 있다. 그 중에서도 시민사회와 민간의 힘이 충분히 성숙하기 전에 성급한 제도 화가 이루어짐에 따라 자원봉사가 문화로 자리 잡는 일에 있어서는 한계에 부딪히고 있다. 본고는 한국국제협력단(Korea International Cooperation Agency, 이하 KOICA) 해외 봉사단(World Friends Korea, 이하 WFK) 사업 운영에 대한 제언을 위해 현재 한국에서 자원봉사의 의미, 자원봉사의 발전과정과 현황 및 성과와 문제점을 짚어보고, 해외자원봉사 활동에 주는 시사점을 알아볼 것이다. 아울러 본인이 속한 세계자원봉사협회의 아태지역 자원봉사 현장 이야기도 담고자 한다. 아태지역은 $\mathrm{KOICA}$ 의 현장과 겹치므로 $\mathrm{KOICA}$ 의 활동에 도움이 될 것으로 판단되기 때문이다. 한국의 자원봉사 발전과정과 현황은 그 범위 가 워낙 광범위하여 본고에 소개하는 내용은 이해를 돕고 시사점을 얻기 위한 부분적인 내용이다. 


\section{II. 자원봉사(volunteering)에 대한 이해: 자원봉사란 무엇인가?}

일반적으로 자원봉사(volunteering)는 '시간적·물질적으로 여유 있는 사람들이 하는 일',

'어려운 사람을 돕는 착한 일' 혹은 ‘좋지만 부담스러운 일'등으로 잘못 이해되는 경향이 있다.

그러나 봉사활동에 꾸준히 참여하는 봉사자들에게 자원봉사에 대한 의견을 물으면, 봉사활동이 란 시간과 노력의 투자가 요구되기는 하지만 결과적으로는 본인 스스로의 성장에도 큰 도움이 된다는 응답이 다수를 이룬다. 즉, 육체적 노력을 통해 타인을 돕고 소통하는 과정에서 자기 스스로의 성장과 인격적 성숙이 동시에 이루어지고, 무엇보다도 사회 구성원들 간에 사회적 신뢰를 쌓을 수 있는 과정이 바로 자원봉사 활동이라 할 수 있는 것이다.

자원봉사는 단순히 타인을 돕는 선행(善行)의 개념을 넘어, 자신이 속한 지역문제에 관여하고 직접 변화를 일구어내는'좋은 시민’이 되는 방법 중의 하나라고 할 수 있다. 가진 자가 가지지 못한 자에게 일방적으로 베푸는 시혜적인(beneficial) 것이 아니라, 현 우리 사회와 생태계가 처한 문제에 적극적으로 대응하기 위해 자신이 속한 공동체에 적극적으로 참여함으로써, 나 자신과 현 세대의 공동체뿐만 아니라 다음 세대 후손들에게도 보다 나은 삶을 보장해줄 수 있는 방안 중 하나로 자원봉사를 이해해야 하는 것이다. 따라서 오늘날을 살고 있는 사회 구성원 들은 자원봉사활동을 통해 본인이 가진 재능과 역량을 타인과 함께 나누고 사회문제에 적극적으 로 참여함으로써 변화를 만들어 내야 한다.

〈그림 1〉 자원봉사의 의미

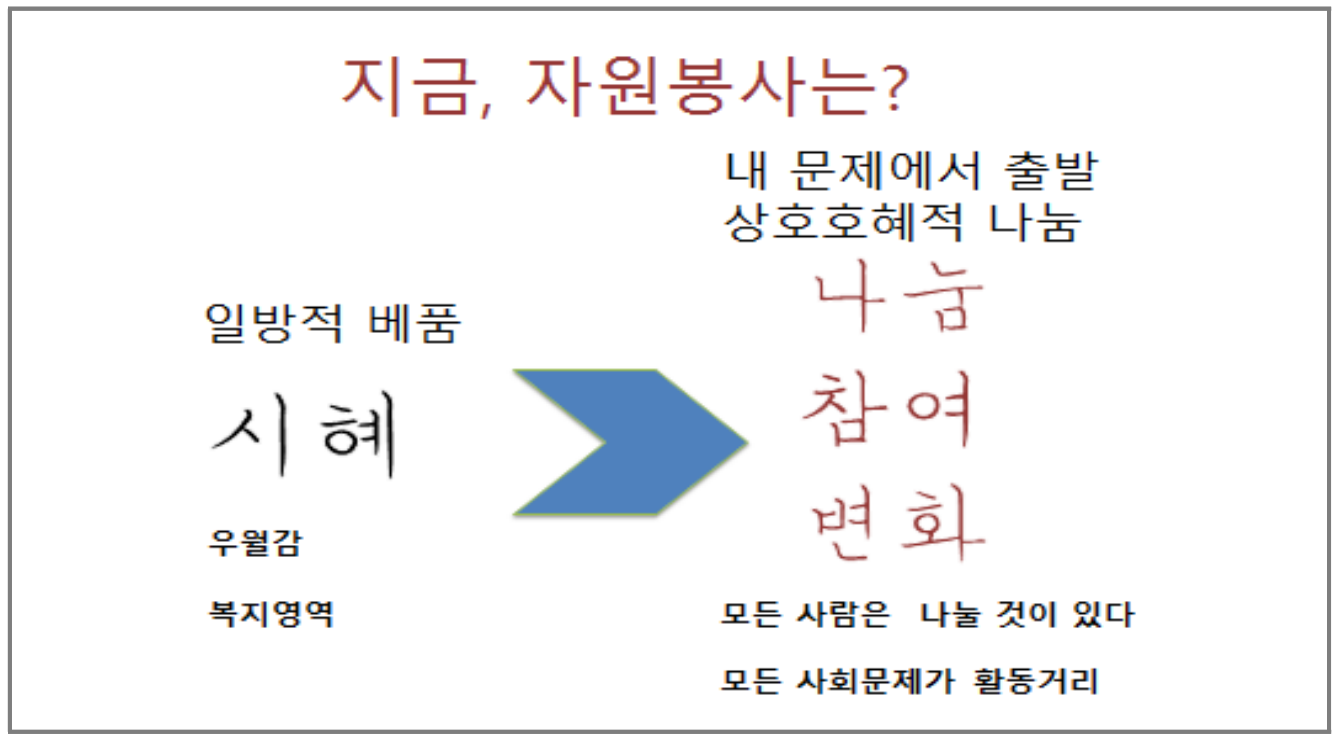

출처: 박윤애 (2016) '자원봉사의 의미와 가치' 강의 자료 
또한 자원봉사는 자신이 속한 지역사회를 스스로가 바라는 형태의 보다 건강한 사회로 만들 기 위해 필요한 것이 무엇인지를 발견하고, 이에 대한 해결방안을 모색해가는 일련의 과정이라 고 할 수 있다. 이러한 과정에서 자신의 관심사와 재능이 긍정적인 변화를 유발하기 위한 중요한 요소로 역할 할 수 있다. 아울러 지역사회의 문제와 변화 방향에 대해 지속적인 관심을 가지고 본인의 재능과 기술로 적극적인 기여를 할 때, 유의미한 변화를 일구기 위한 지속적인 활동 또한 가능하다. 이것이 바로 지속가능한 발전(sustainable development)을 가능케 하는 주요 기제 중의 하나로 작동한다고 할 수 있다.

\section{III. 현대적 의미의 한국자원봉사의 발전과정 및 현황}

\section{1. 한국 자원봉사의 주요 발전 연혁}

그렇다면 한국에서 자원봉사가 어떠한 흐름으로 발전해왔는지에 대해 먼저 살펴볼 필요가 있다. 한국 자원봉사 발전상의 중요 이정표를 간단히 정리하면 다음과 같다 (<표 $1>$ 참조).

〈표 1〉 한국 자원봉사 발전상의 주요 이정표(1988-현재)

\begin{tabular}{c|l}
\hline 1986 & 86 서울 아시안게임 자원봉사 \\
\hline 1988 & 88 서울 올림픽 자원봉사 \\
\hline 1993 & 대전 엑스포, 미국 자원봉사대회 참가 \\
\hline 1994 & 중앙일보 자원봉사사무국 설치, 제1회 자원봉사대축제, 한국자원봉사협의회 창립 \\
\hline & $\begin{array}{l}\text { 최초의 기업 자원봉사단인 삼성사회봉사단 설립 } \\
\text { 선진국 자원봉사 인프라 2차 연수 실시 } \\
\text { 충고생 자원봉사 연간 40시간 필수 } \\
\text { 대학 사회봉사협의회 창립, 대학 사회봉사과목 개설(한양대) }\end{array}$ \\
\hline 1995 & $\begin{array}{l}\text { 행정자치부에서 시군구 단위의 자원봉사센터가 설립 시작, 정무제2장관실(1992), } \\
\text { 보건복지부(1992), 문화관광부(1996)에서 각기 독자적 자원봉사 인프라 설치 }\end{array}$ \\
\hline 1996 & 제 6차 IAVE 아태지역 자원봉사대회 개최(서울) \\
\hline 2001 & UN 세계자원봉사의 해(IYV) 기념, 전국 자원봉사 물결운동 \\
\hline 2002 & 한일 월드컵 대회 자원봉사, 제17차 IAVE 세계자원봉사대회 개최(서울) \\
\hline 2005 & $\begin{array}{l}\text { 자원봉사기본법 제정 } \\
\text { 자원봉사센터의 민영화 지향 } \\
\text { 자원봉사 인프라에 대한 법적 지원 근거 마련 }\end{array}$ \\
\hline 2007 & 제1차 자원봉사진흥 국가 5개년 기본계획 수립 \\
\hline $2007-2008$ & 태안 기름유출 사고 기름제거 자원봉사 실시
\end{tabular}




\begin{tabular}{|c|c|}
\hline 2011 & 제 13차 IAVE 아태지역 자원봉사대회 개최(경남 창원) \\
\hline 2012 & $\begin{array}{l}\text { 여수엑스포 자원봉사 실시(한국자원봉사협의회 주관) } \\
\text { 제 2차 자원봉사진흥 국가 } 5 \text { 개년 계획 수립 }\end{array}$ \\
\hline 2014 & 세월호 사건 관련, 전국 분향소 및 안산, 진도, 팽목항 현장 자원봉사 실시 \\
\hline 2016-2018 & $\begin{array}{l}\text { 한국자원봉사의 해 선포(현 진행 중) } \\
\text { 평창 동계올림픽 자원봉사 준비 및 실시 }\end{array}$ \\
\hline 2017 & 제 3차 자원봉사진흥 국가 5개년 계획 수립 준비 중 \\
\hline
\end{tabular}

출처: 이강현 · 박윤애 $(2011,2016)$ '한국자원봉사의 발전과정' 강의자료

우리나라의 자원봉사는 86 서울아시안 게임과 88 서울올림픽을 계기로 일반 대중에게 그 의미가 알려지기 시작했다. 이후 민간 차원에서 자원봉사의 중요성을 인식하고 미국의 촛불재단 등 민간 자원봉사 단체들, 기업 자원봉사, 대학의 자원봉사 등 자원봉사 운영체계를 둘러보는 연수를 두 차례 진행하였고, 이를 계기로 한국자원봉사협의회, 한국자원봉사포럼, 한국 대학사 회봉사협의회, 삼성사회봉사단 등 주요 민간 자원봉사단체들과 기업 자원봉사단이 창립하는 계기가 되었다. 또한 중앙일보가 언론으로서는 최초로 자원봉사 섹션을 만들고, 1994년부터 자원봉사대축제를 진행하여 자원봉사 활성화 노력을 기울여왔다.

자원봉사 활성화를 지원하는 인프라 설립도 활발하게 진행되었는데, 1984년부터 1992년까지 여성개발원에서 여성자원활동 인력은행을 운영해오다 1992년부터 정무 제2장관실에서 여성자 원활동센터를 설립 운영하기 시작하였다. 1992년 보건복지부가 재가복지봉사센터, 1996년에는 문화관광부가 청소년 자원봉사센터를 시작하였다. 1996년부터는 행정자치부 산하로 시군구 단위의 자원봉사센터가 설립되기 시작하였고, 2003년 말까지 전국에 248개의 자원봉사센터가 설립되었다. 2005년 자원봉사기본법이 통과된 후 2007년부터 자원봉사진흥을 위한 국가 기본 계획이 5년마다 수립, 시행되고 있다.

몇 번에 걸친 파주 홍수와 태풍 루사 등의 자연재해와 태안 기름유출 사고, 세월호 사건 등 재난이 터질 때마다 자원봉사자들은 발 벗고 나서서 피해복구와 유가족 지원 등의 큰 역할을 담당해왔다. 또한 2002년 한일 월드컵, 2012년 여수 엑스포 등 국가의 큰 행사가 있을 때에도 자원봉사자들은 민간 외교사절로서 정부가 미처 하지 못하는 틈새를 메워 왔으며, 2018년 평창 동계올림픽을 앞두고도 2만 명이 넘는 자원봉사자들을 선발하여 교육하고 있다.

2016년부터는 자원봉사의 재도약을 위해 '2016-2018 한국자원봉사의 해’를 선포하여 자원 봉사 캠페인과 프로그램 개발, 자원봉사 정책 재정립 노력을 진행 중이다. 


\section{2. 한국 자원봉사 운영 현황: 2014 년도 자원봉사실태조사 분석 결과 중심으로}

사단법인 한국자원봉사문화(Volunteering Culture Korea, 전 볼런티어21)에서는 행정자 치부의 지원 하에 한국갤럽과 함께 1999년부터 매 3개년 주기로 2014년까지 국내 '자원봉사실 태조사'를 실시하고 있다. 아래 <그림 2>는 동 자원봉사실태조사 분석 결과를 바탕으로 살펴 본 1999년부터 2014년까지 대한민국 국민의 자원봉사 참여율 추이를 보여준다. 동 변화 추이 를 살펴보면, 우선 2014년 자원봉사 참여율은 22.5\%로, 2014년 조사대상자 20세 이상 성인 1,500 명 중 337명이 2014년 한 해 동안 자원봉사에 참여하였다. 동 수치는 3년 전인 2011년의 참여율 $21.4 \%$ 보다 $1.1 \%$ 상승한 수치이다. 아래 <그림 2>에서 알 수 있듯이, 1999년 이후 자원봉사 참여율의 전체 추이를 보면 1999년부터 2005년까지는 지속적으로 증대하였으나, 2005년 이후 현재까지는 자원봉사 참여율이 21-22\% 수준에 계속 정체되어 있음을 알 수 있다.

〈그림 2〉 자원봉사 참여율 추이 (1999-2014)



출처: 주성수 외 (2014)

또한 2011년, 2014년 동안의 자원봉사활동에 대한 정기적인 참여 비중 및 현황을 살펴보면 아래 <그림 3>과 같다. 먼저 2014년 조사 결과, 정기적으로 봉사활동에 종사한다'는 자원봉사자는 전체 1,500 명 중 $37.7 \%$ 이며, 그 중 ‘주 1 회 이상 활동' 자원봉사자 비중은 $30 \%$, '월 1 회 이상 활동' 자원봉사자 비중은 $42.5 \%$ 이다. 동 수치는 2011년과 비교하였을 때 각각 $36.9 \%, 43.3 \%$ 였다 는 점과 비교해볼 때 정기 활동자 수가 상당 수준으로 줄었음을 알 수 있다. 이처럼 정기 자원봉사 참여율이 감소한 주요한 요인 중의 하나는 자원봉사활동의 질적 수준이 봉사자들의 수요 및 현 봉사활동에 대한 변화 흐름에 맞추어 제대로 향상되지 못하고 있다는데서 찾을 수 있다. 
20 세 이상 인구 4,130 만 3,341 명 중 조사에서 나타난 자원봉사인구(22.4\%)를 추정해보면 $9,293,252$ 명이고, 자원봉사의 경제적 가치 추정치는 7 조 9,877 억 원으로 2011 년의 절반 수준 이다.

\section{제I 장}

출처: 주성수 외 (2014)

또한 동 2014 '자원봉사실태조사'에서는 자원봉사 참여자들의 봉사 참여에 대한 참여 동기가 무엇인지에 대한 분석결과를 제시하고 있다(<그림 $4>$ 참조). 동 분석 보고서에서는 개인의 자원봉사 참여 동기를 '도구적(instrumental)'동기와 '의무감(sense of duty)' 동기로 크게 구분하고 있다.2) 먼저 2014년 자원봉사자의 참여 동기는 ‘도구적' 동기가 되는 '여가시간 활용' 과 ‘다양한 경험’이 가장 많다. 다음으로 '의무감' 동기가 되는 '도덕적 의무와 책임', '사회문제 해결’이 주요 동기로 나타난다. 2011년과 비교해보면, ‘도구적’ 동기가 ‘의무감' 동기를 크게 앞서는 특징이 부각된다. 다음에 나오는 ‘스스로 위로받기’와 ‘새로운 사람 만나기’도 도구적 동기로 2011년에 비해 크게 늘어난 특징이 있다. 반면에 ‘도덕적 책임', ‘사회문제 해결' ‘많이 가진 자의 의무'등 의무감 동기들은 크게 줄었음을 알 수 있다.

2) 자원봉사활동의 동기는 이타주의, 도구주의, 의무감 등 다양하다(Clary et al. 1998: 주성수, 2005: 53). 자원봉사활동의 동기는 기본적으로 이타주의 이외에도 경험을 쌓기 위해서, 자기성장을 위해서 등의 도구적인 동기(주성수, 2005: 53) 또는 시민, 국민으로서의 당연한 의무로 봉사활동에 참여하는 의무감(sense of duty)을 들 수 있다. 
〈그림 4〉 자원봉사 참여의 개인적 동기 $(2011,2014)$

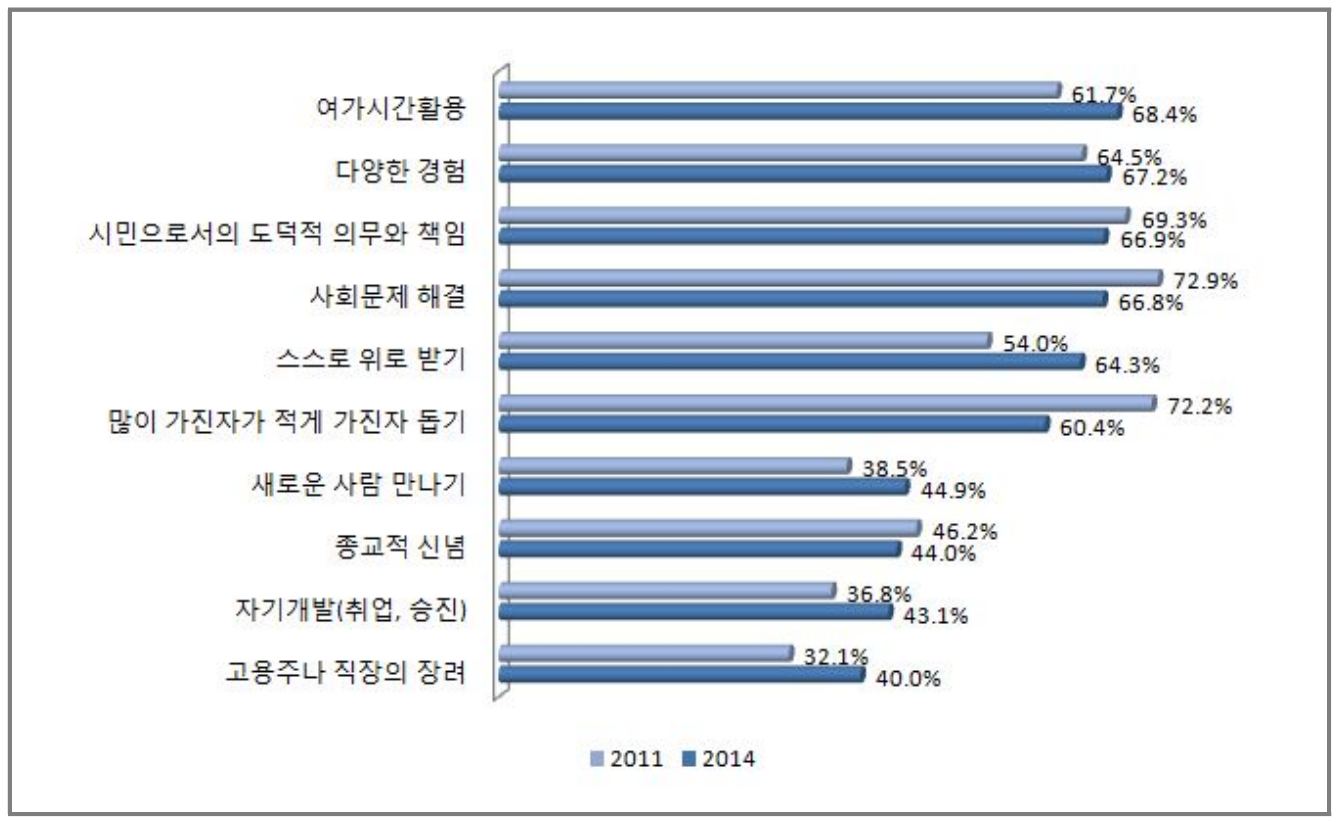

출처: 주성수 외 (2014)

그렇다면 봉사활동은 어떠한 경로를 통하여 처음 접하게 될까. 동일 분석 보고서의 내용에 따르면, 자원봉사는 조직(단체)을 통한 활동이라는 점에서 2014년 자원봉사자의 참여 경로 또한 '소속된 단체(종교단체 포함)나 조직, 학교 및 직장’을 통한 참여가 $47.3 \%$ 로 가장 많다. 동 참여 경로는 2011년과 비교하면 약 5.3\% 정도 감소한 수치이나, 2011년과 2014년 모두 가장 높은 비중을 보여주고 있다. 반면에 두 번째 우선순위가 되는 '누구로부터의 요청’으로 인한 자원봉사 참여 방식은 2011년과 비교하였을 때 약 5.5\%가 증가한 $33 \%$ 비중을 보임으로써 보다 중요한 참여 경로가 되고 있음을 알 수 있다. 또한 '자원봉사활동을 하는 가족이나 친구가 있어서'참여하게 되었다는 비중도 2 개년 모두 약 $22 \%$ 로 적지 않은 비중을 유지하고 있다. 이에 반해 전국 시도, 시군구에서 운영되는 '자원봉사센터'를 통한 참여 경로는 $6 \%$ 수준에 계속 머물러 있으며, ' 1365 자원봉사포털(VMS)' 또한 지속적으로 $5 \%$ 내외를 유지함으로써 참여 경로로서의 영향력은 크게 늘지 않고 있다고 할 수 있다(<그림 5> 참조). 
〈그림 5〉 지원봉사 최초 참여 경로 $(2011,2014)$



출처: 주성수 외 (2014)

\section{3. 자원봉사단체}

우리나라 자원봉사에 있어 민간의 대표 법정기구로는 한국자원봉사협의회3)가 있다. 아래 $<$ 박스 $1>$ 에서와 같이 「자원봉사기본법」 제 17 조에 따르면 다음과 같이 한국자원봉사협의회 의 사업근거와 사업 내용을 명시하고 있다.

\section{〈박스 1〉자원봉사기본법 제 17 조 자원봉사협의회 설립근거}

[자원봉사기본법 제 17 조] 자원봉사단체는 전국 단위의 자원봉사활동을 진흥 - 촉진하기 위한 다음 각 호의 활동을 하기 위하여 한국자원봉사협의회를 설립할 수 있다.

1. 회원단체 간의 협력 및 사업 지원

2. 자원봉사활동의 진흥을 위한 대국민 홍보 및 국제교류

3. 자원봉사활동과 관련된 정책의 개발 및 조사 - 연구

4. 자원봉사활동과 관련된 정책의 건의

5. 자원봉사활동과 관련된 정보의 연계 및 지원

6. 그 밖에 자원봉사활동의 진흥과 관련하여 국가 및 지방자치단체로부터 위탁받은 사업

출처: 자원봉사기본법

3) 한국자원봉사협의회 기관에 대한 상세사항은 홈페이지에서 확인가능하다. (http://vkorea.or.kr) (접속일: 2017.4.14) 
동 협의회에는 현재 총 119 개 단체가 참여하고 있는데, $\triangle$ 국립공원관리공단을 비롯한 6 개의 공공기관, $\triangle$ 삼성사회봉사단을 포함한 15 개의 기업, $\triangle$ 대한적십자사, 새마을운동, 아름다운가 게 등 41 개의 시민사회단체, $\triangle$ 사회복지협의회 등 20 개의 사회복지단체, $\triangle$ 대한불교조계종사회 복지재단, 한국교회봉사단 등 7 개의 종교단체, $\triangle$ 한국자원봉사센터협회, 한국자원봉사포럼 등 8 개의 자원봉사 전문단체, $\triangle$ 제주특별자치도 자원봉사협의회 등 5 개의 지역협의회, $\triangle$ 대한약사 회 등 5 개의 직능단체, $\triangle$ 대학사회봉사협의회 등 3 개의 학교 관련 단체, $\triangle$ 국제개발민간협의회 등 7 개의 국제협력 단체가 속해 있다. 회원으로 있는 협의회와 단체, 기관 자체가 수많은 지역 네트워크를 가지고 있는 곳들이 많아 매우 광범위한 조직이라 할 수 있다.

자원봉사 전문단체들 중에 한국자원봉사센터협회4)는 전국 245 개 센터 중 223 개의 자원봉사 센터가 회원으로 참여하고 있으며, 정부 주요 부처 및 지방자치단체에 자원봉사센터의 역할과 기능을 인식시키는 일과 지역사회 발전을 위한 자원봉사센터들의 역할 정립, 그리고 자원봉사계 의 현안과제 해결 등의 노력을 기울이고 있다.

한국자원봉사포럼(Korea Forum of Volunteerism)은 선진국 자원봉사연수를 함께 다녀온 전문가들이 1995년 창립하여 시민자원봉사헌장 제정, 자원봉사계 현안과제 정책토론 등 한국자 원봉사학회(Korea Academy of Volunteerism)와 더불어 자원봉사계의 정책수립과 연구 활동 을 하고 있다. 한국자원봉사문화는 1996년에 창립하여 자원봉사 프로그램 개발, 지도자 양성, 전국자원봉사실태조사연구 등의 연구, 기업 자원봉사 컨설팅, 프로보노 자원봉사 등의 사업을 하고 있다. 자원봉사이음(Volunteering Connected, 전 한국자원봉사관리협회)은 자원봉사 실무 자, 활동가들의 인적네트워크로서‘자원봉사관리자 윤리강령'5)을 제정, 보급하고 있으며, 성장을 돕기 위한 소모임 운영, 매년 12 월 5일 세계자원봉사의 날 한 달 전인 11 월 5 일을 ‘국제 자원봉사관 리자의 날로 기념하여 현장 활동가들의 활동을 독려하고 시상하는 일 등을 하고 있다.

\section{4. 자원봉사센터6)}

자원봉사센터는 「자원봉사기본법」 제 19 조에 그 설립근거가 있으며, 자원봉사를 필요로

4) ‘한국자원봉사센터협회’에 대한 자세한 사항은 홈페이지를 참조하기 바란다. (http://www.kfvc.or.kr/) (접속일: 2017.4.14)

5) 동 윤리강령에는 자원봉사자, 조직, 사회에 대한 윤리 기준이 포함되어 있다. 자세한 사항은 자원봉사이음 홈페이지에서 확인가능하다. (https://www.volunteereum.org/ethics) (접속일: 2017.4.14)

6) 동 절은 행정자치부에서 발간한 “2016년 자원봉사센터 현황”의 내용을 바탕으로 발췌, 정리하였다. 동 자료집의 내용은 다음에서 확인 가능하다: https://www.moi.go.kr/frt/bbs/type001/commonSelect BoardArticle.do? bbsId=BBSMSTR_000000000059\&nttId=56772f（접속일:2017.4.14） 
하는 곳과 자원봉사를 희망하는 시민들을 연결하는 역할을 하기 위해 시군구 단위로 설립되었 다. 재원은 지자체의 지원이 대부분을 차지하며, 행정자치부로부터 두 명의 인건비와 자원봉사 자 보험료 지원을 받고 있다. 행정자치부는 한국자원봉사협의회와 한국자원봉사센터협회에 위 탁하여 한국중앙자원봉사센터 운영을 지원하고 있다. 자원봉사센터는 지역 내 자원봉사 가치 확산을 위한 홍보, 자원봉사 관련 단체/기관 실무자와 리더, 봉사자들의 역량 강화를 위한 교육, 지역 내 풀뿌리 소모임의 성장을 지원하기 위해 지역문제 해결을 위한 자원봉사 프로그램 공모 전 등 자원봉사 프로그램 개발과 보급, 유관 기관, 기업과의 네트워킹, 자원봉사 인정, 자원봉사 실적 관리 등의 업무를 담당하고 있다.

전국에 분포되어 있는 각 지역의 자원봉사센터 중에는 그 설립 역사가 20년 이상 되는 곳들도 다수이며, 이러한 센터들의 경우 해당 지역의 자원봉사 진흥에 있어 중추적인 역할을 효과적으 로 수행하고 있다고 할 수 있다. 하지만 실질적인 운영 사정을 살펴보면, 자원봉사센터 종사자들 의 오랜 실무 역량과 노하우에도 불구하고 해당 지자체의 지역주민을 위한 자원봉사 허브 기능 으로서의 자원봉사센터의 역할에 대한 이해 부족 및 민간의 역량 한계 등의 요인으로 인해 아직도 많은 해결과제들에 직면해있는 것이 사실이다. 이는 자원봉사센터가 지자체의 예산지원 을 받는 구조 하에 있다는 점에서, 지역사회 시민들의 수요(needs)보다는 지자체의 요구사항을 고려할 수밖에 없으며, 이로 인해 때로는 지자체에 대한 동원성과 일회성 행사로 자원봉사자들 이 움직여야 하는 문제 상황이 종종 발생한다. 또한 국민의 세금으로 지원을 받는 자원봉사센터 가 해당 지역의 자원봉사 활성화를 위한 플랫폼으로서의 제 역할을 성공적으로 수행해야 함에도 불구하고, 지역사회 내 기 존재하는 자원봉사조직과 경쟁구도 속에 놓이게 됨에 따라 지역이 민간 자원봉사조직의 자생능력을 약화시키는 문제를 간혹 유발하기도 한다.

2016년 말 행정자치부가 발간한『자원봉사센터 현황』자료집에 따르면 2015년 기준 전국에 시군구 단위로 245 개의 자원봉사센터가 존재하며, 이 중 $53.9 \%$ (132개)가 직영, $20.4 \%$ (50개) 가 위탁, 25.7\%(63개)가 법인으로 운영되었다. 또한 자원봉사센터에 근무하는 종사자 수는 1,451 명이며, 이 중 $90 \%$ 가 민간인, $10 \%$ 가 공무원이었다. 종사자 중 근속연수가 10 년 이상은 $9.6 \%, 5$ 년 이상은 $23.3 \%$ 였으며, 한 센터 당 평균 5.5 명이 근무하고 있는 것으로 나타났다. 한 센터 당 평균 예산은 92,317천 원이었다.

센터에 등록된 인원은 약 1,140 만 명이며 이는 인구 대비 $22.4 \%$ 에 해당한다. 이 중 1 년 간 한 번 이상이라도 자원봉사활동을 한 사람의 비율은 $32.9 \%(3,746,577$ 명 $)$ 이며, 여성은 $56.9 \%$, 남성은 $43.9 \%$ 였다. 직업별로는 자영업이 $14.4 \%$ 로 가장 많았고, 주부가 $11.6 \%$ 로 그 뒤를 이었다. 
〈표 2〉 2015년 국내 자원봉사센터 현황

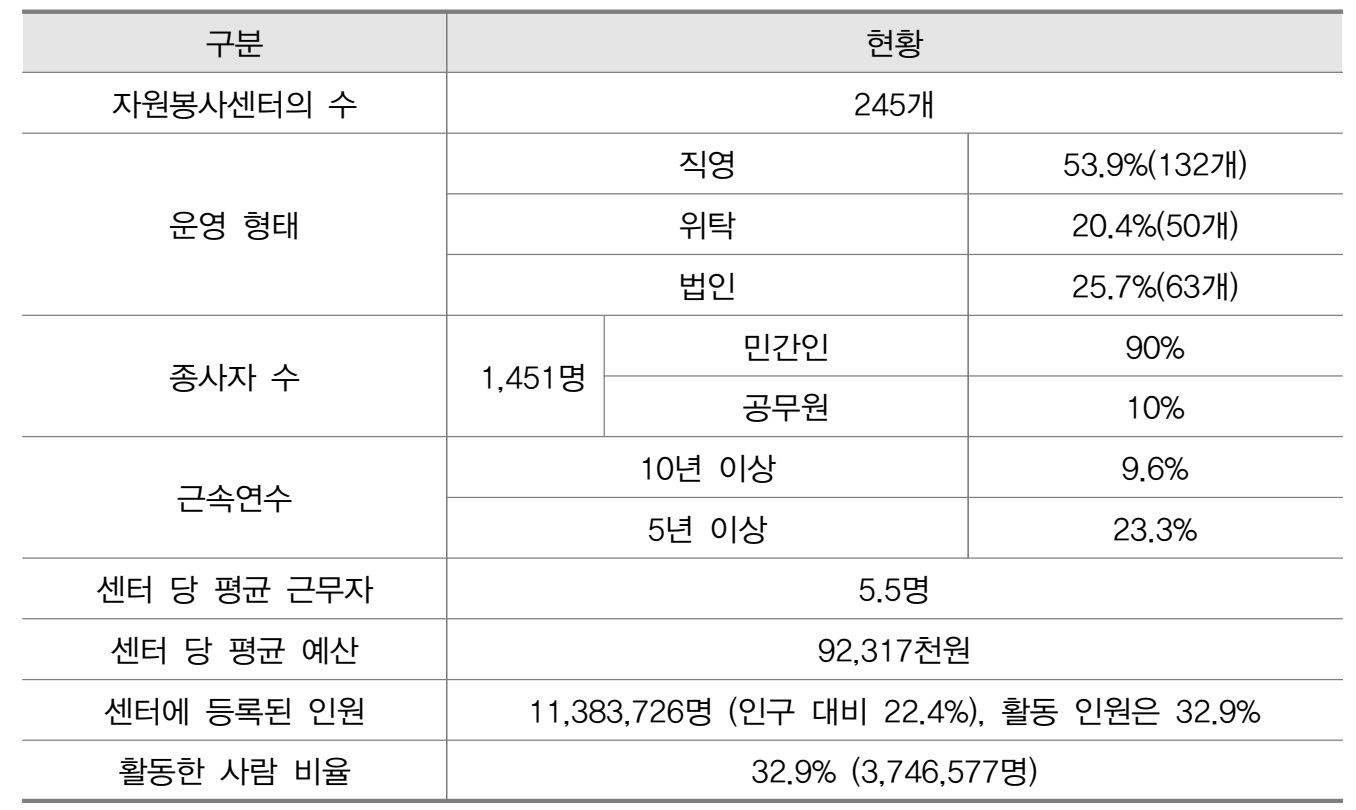

출처: 행정자치부 ${ }^{\circledR 2016 ㄴ ㅕ ㄴ ~ ㅈ ㅏ ㅇ ㅝ ㄴ ㅂ ㅗ ㅇ ㅅ ㅏ ㅅ ㅔ ㄴ ㅌ ㅓ ~ ㅎ ㅕ ㄴ ㅎ ㅘ ㅇ 』 ㅈ ㅏ ㄹ ㅛ ㅈ ㅣ ㅂ ~}$

\section{IV. 국내 자원봉사 활성화 노력}

정부는 대규모 행사 개최 또는 긴급 재난 발생 시 자원봉사자들의 참여와 역할의 중요성을 강조하며, 전국 각 지역에 자원봉사센터를 설립하는 등 제도적 인프라 설립 및 지원뿐만 아니라, 2005년 「자원봉사기본법」이 통과된 이후 2006년 동 법 시행령을 발표하고, 2007년부터는 $\ulcorner$ 제 1 차 자원봉사 진흥 국가기본계획」까지 수립, 실시하고 있다. 이러한 법적·제도적 기반에 의거하여 우리 정부는 학생 자원봉사, 대학생 자원봉사 등과 같이 봉사활동을 보다 조직적이고 체계적으로 확대 운영하기 위해 지속적으로 노력하고 있으며, 기업들 또한 다양한 봉사활동 프로그램을 운영함으로써 자사 임직원들의 적극적인 자원봉사활동 참여를 독려하고 있다. 이렇 게 국내에서 봉사활동 개최 및 참여주체의 범위는 지속적으로 확대되고 있으며, 동 절에서는 국내에서 실시되고 있는 다양한 봉사활동 활성화 노력 현황에 대해 소개하고자 한다. 여기서는 기업 자원봉사에 대한 언급은 제외하겠다. 


\section{1. 정부의 노력}

\section{가. 자원봉사 국가기본계획}

제 I 장

2005년 「자원봉사기본법」 제정을 계기로 이후 5년 단위로「자원봉사 진흥을 위한 기본계 획」을 수립하여 진행하고 있다. 「자원봉사활동 진흥을 위한 국가기본계획」은 민관협력을 바탕 으로 하되 자원봉사의 실행주체는 민간이며, 이를 정부가 지원한다는 근본정신을 갖고 있다. 동 기본계획은 현재 자원봉사 진흥을 위한 걸림돌이 무엇인지, 진흥을 위해 필요한 정책과제는 무엇 인지 전문가 조사 등을 통한 의견수렴 절차를 거쳐 5 개 영역의 정책방향으로 진행하고 있다.

「제 2차 자원봉사 진흥을 위한 기본계획(2013-2017)」의 경우, 자원봉사 문화와 참여, 자원 봉사 인프라, 자원봉사 관리와 개발, 자원봉사 연구와 평가 그리고 자원봉사 글로벌 협력으로 정하여 진행하고 있다. 이 5 개 영역은 자원봉사 진흥을 위한 모든 내용을 담고 있으며, 각 시도별로 매 년 각 영역별 시행계획을 수립하도록 하여 진행하고 있다. 올해는 제 2차 기본계획 의 이행 여부 평가와 함께 「제 3 차 국가기본계획」이 수립될 예정이다. 제 1,2 차 기본계획은 아래와 같다.

〈표 3〉 자원봉사활동 진흥을 위한 제 $1 \cdot 2$ 차 국가기본계획

\section{비전} 제 2차 (2013-2017) 참여와 나눔, 지속가능한 미래


\section{1 성숙한 자원봉사 문화의 확산 \\ 2 생애주기별 시민참여 확대 \\ 3 시민사회의 역량 강화}

\section{자원봉사 문화와 참여}

- 자원봉사문화의정립과확산: $\boldsymbol{\Delta}$ 자원봉사의 개념 정의 통일 $\Delta$ 자원봉사의 자발성과 무급성 가치 증진 $\Delta$ 자원봉사 홍보와 캠페인

- 정부-기업-시민사회파트너십: \시도 평생교육 자원봉사대학 운영 $\Delta$ 자원봉사 행사와 축제 지원

- 생 애 주 기 별 자 원 봉사 참 여 확 대 : $\Delta$ 학생 자원봉사 활성화 $\Delta$ 직장인 자원봉사와 재능나 눔 활성화 $\triangle$ 은퇴자 및 노인 자원봉사 활성화

\section{지원봉사 지원 인프라}

- 제도및정책정비: \기본법령 개정 및 관련법 재정비 \자원봉사 진흥위원회 활성화

- 민간인프라확립:민간 자원봉사 대표기관 역할 강화 $\Delta$ 자원봉사센터 역할 재정립 \자원 봉사단체 육성 및 지원 확대 
- 물적인프라구축: \자원봉사 진흥기금 조성 \자원봉사 전산시스템 개선

\section{자원봉사 관리와 개발}

- 자원봉사활동관리체계화및관리자양성: \자원봉사활동 관리 체계 표준모형 개발 및 보급 $\Delta$ 자원봉사활동 관리자 교육 및 자격과정 표준화 사원봉사관리자 교육 및 훈련 프로그램 지원

- 자원봉사시민리더십육성및자원봉사프로그램개발: \지역사회 자원봉사 리더 육성 $\Delta$ 부 처별·지역별 자원봉사 특성화 프로그램 개발

\section{자원봉사 연구와 평가}

- 자원봉사활동실 태조사: \전국 자원봉사활동 실태조사 $\Delta$ 전국 분야별 자원봉사자 실태 조사 $\Delta$ 자원봉사센터 운영 실태조사 $\Delta$ 자원봉사단체 운영 실태조사

- 자원봉사연구활동지원: \한국자원봉사백서 국.영문 발간 $\Delta$ 자원봉사 전문 학술지 발간 지원 \정책과제 연구 활동 지원

- 자원봉사평가체계개선및평가시행: \자원봉사센터 평가체계 개선 및 시행 \정부 자원봉 사정책 성과 평가

\section{자원봉사 글로벌 협력}

- 자원봉사국제개발협력활성화: \전 자원봉사 국제 개발 협력 프로그램 개발 $\Delta$ 해외자 원봉사 프로그램 정비 및 개발

- 자원봉사국제교류활성화: \자원봉사 국제교류 프로그램 정비 및 개발 \국제교류 해외네 트워크 확대 및 강화

- 자원봉사국제사업관리체계구축: \자원봉사 국제사업 관리 체계 구축

출처: 주성수 외 (2012)

\section{나. 자원봉사 종합 안내시스템: 시간실적 관리 정책의 한계}

각 정부 부처에서는 자원봉사 활동과 교육정보를 종합적으로 안내하기 위해 '자원봉사 종합 전산시스템’을 운영하고 있다. 행정자치부는 ' 1365 자원봉사포털'을, 여성가족부는 청소년을 위한 ‘두볼(Dovol),' 보건복지부는 '사회복지 자원봉사 인증관리시스템’을 운영하고 있다.7) 그 동안 상호 연계성이 낮음에 따라 현장에서 중복 관리 등의 많은 문제들이 제기되어 왔는데, 최근에는 각 부처별 시스템 간 상호 연계가 가능하게 되었다.

그러나 이러한 전산시스템들의 경우 자원봉사에 대한 개별 시간 입력 데이터와 실적관리 데이터 모두를 포함하여 시스템 상에서 관리하는 데이터의 양이 상당하다는 점에서 기술적인

7) 본문에서 소개된 각 정부 부처의 자원봉사전산시스템은 다음에서 확인 가능하다: $\triangle$ 행정자치부 ' 1365 자원봉사포털: https://1365.go.kr, $\triangle$ 여성가족부 '두볼(Dovol): http://dovol.youth.go.kr, $\triangle$ 보건복지부 '사회복지 자원봉사 인증 관리시스템': http://www.vms.or.kr/index.jsp (접속일: 2017.4.15) 
차원에서 해결해야할 부분들 또한 현존하는 것이 현실이다. 가령 ' 1365 자원봉사포털'의 경우 종종 전산시스템 과부하가 지속적인 문제로 대두되어옴에 따라 행정자치부는 기존의 전산시스 템보다 한 단계 위의 성능을 갖는 시스템을 구축함으로써 동 문제를 해결하였다. 그러나 전산시 스템이 갖는 근본적인 문제 해결을 위해서는 여전히 많은 해결과제가 남아 있다. 그 중에서도 주요 문제점 중의 하나는 전산시스템이 보다 시민 수요 중심으로 설계 및 운영되어야 한다는 점이다. 가령, ' 1365 자원봉사포털'시스템의 경우 2015년도에 해당 시스템을 대상으로 한 문제 가 최고조에 달함에 따라 전국의 자원봉사센터들이 이에 대해 성명서까지 내는 상황이 발생하였 는데, 당시 지적된 문제의 핵심은 행정자치부의 동 포털이 시민 중심이 아니라 정부 입장의 통계와 관리 위주로 설계되었다는 점이었다. 당시 한국자원봉사센터협회가 제시한 "1365 자원 봉사포털시스템 정상화를 위한 결의문”의 주요 내용을 보면 다음과 같다.

제I 장

“상식적으로 자원봉사관리시스템은 자원봉사 관리를 효율적으로 운영하기 위 한 시스템이어야 하며 사용자인 센터관리자 및 이용자인 자원봉사자들의 눈높이 와 편익을 위해 존재함이 마땅합니다. 그럼에도 불구하고 현재의 자원봉사관리 시스템은 자원봉사자 및 시민 중심이 아니라 등록, 통계 등의 시스템 위주로 구성되어있다는 점에서 태생적 한계를 가지고 있습니다." (한국자원봉사센터협 회, 2015)8)

궁극적으로 자원봉사 개별 시간 수 적립이라는 현 정책은 개선될 필요가 있다. 이를 위해 전산입력과 시스템 정비 등 행정관리와 시스템에 소요되는 엄청난 예산낭비 문제와 무엇보다 자원봉사가 시간 수 적립이라는 자원봉사의 가치에 대한 잘못된 인식이 확산되는 것을 막는 근본적인 대책이 필요한 상황이다.

\section{2016-2018 한국자원봉사의 해 선포}

보다 많은 샘플을 갖고 청소년들까지 포함하는 통계청 조사9)에서도 자원봉사 참여율은 1991 년 13.0\%, 2003년 14.6\%, 2006년 14.3\%, 2009년 19.3\%, 2011년 19.8\%, 2013년 19.9\%, 2015년 18.2\%로, 20\%를 밑돌고 있는 수준이라는 점에서 정체 상태라고 할 수 있다(아래<그 림 6> 참조). 상기에서 살펴본 바와 같이 정부 차원에서 많은 노력이 이루어지고 있음에도

8) 한국자원봉사센터협회가 제출한 “ 1365 자원봉사포털시스템 정상화를 위한 결의문”의 전문은 서울시자원봉사센터 홈페이지에서 확인가능하다. (http://volunteer.seoul.go.kr/news/notice/view/986?keyword= \&searchField= \&page=8) (접속일: 2017.4.15)

9) 통계청이 제시하는 자원봉사 참여율 그래프 및 통계표는 통계청 국가지표체계 웹페이지에서 확인가능하다. http://www. index.go.kr/potal/main/EachDtlPageDetail.do?idx_cd=2988 (접속일: 2017.4.16) 
불구하고 실제 우리나라의 자원봉사 참여율이 정체되어 있다는 사실은 정부 차원의 노력이 비효율적으로 이루어지고 있을 가능성을 제기한다고 할 수 있다. 따라서 정부의 지나친 제도화 노력들이 오히려 인프라 중복과 예산 낭비를 낳고, 전산시스템을 통한 시간실적관리로 인해 자원봉사가 실적을 쌓는 일로 인식되는 등 오히려 자원봉사를 부정적으로 보게 되는 부작용을 만들어내는 것은 아닌지 돌아볼 필요가 있다.

〈그림 6〉 통계청 발표 우리나라 자원봉사 참여율(1999-2015)

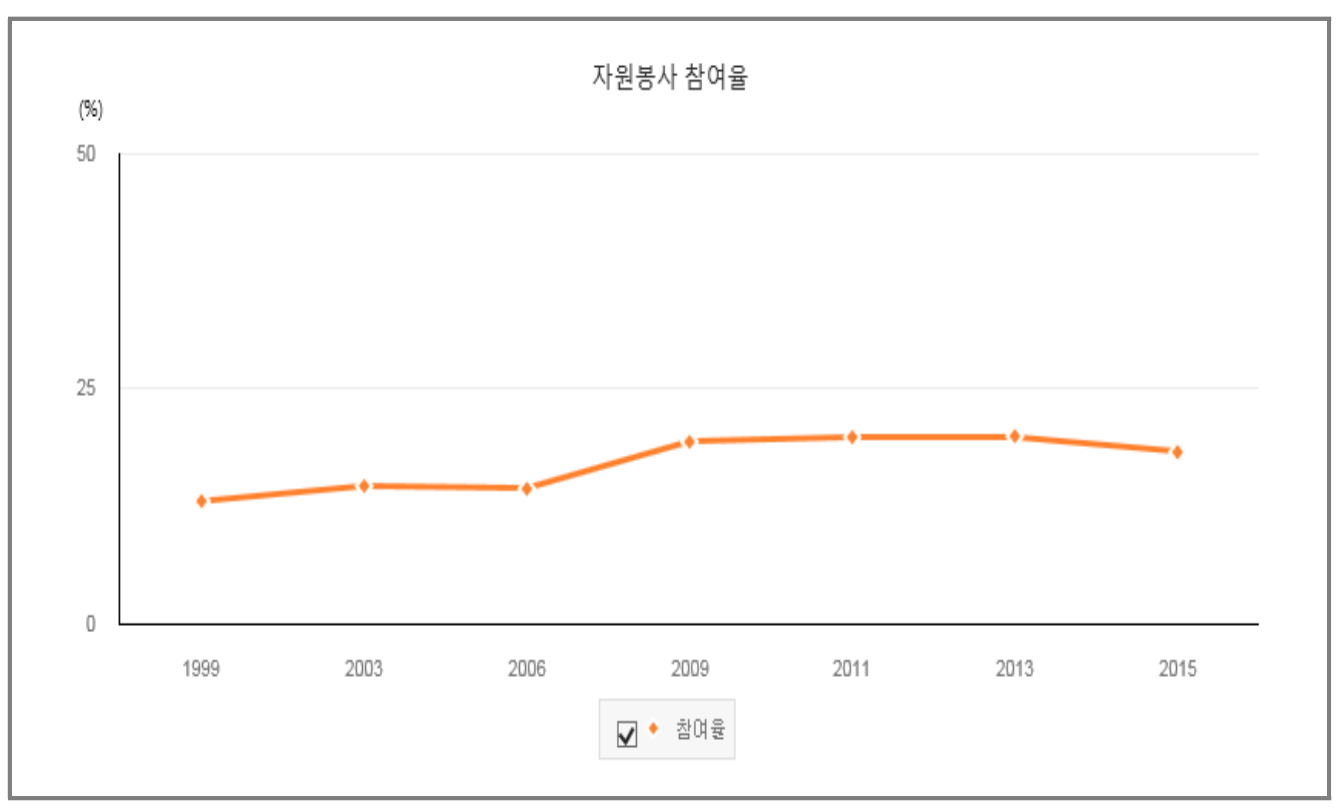

출처: 통계청 국가지표체계 사이트 (http://www.index.go.kr) (접속일: 2017.4.16)

이러한 문제의식에서 2015년 말 한국자원봉사협의회와 행정자치부가 공동으로 '2016-2018 한국자원봉사의 해(Korea Year of Volunteering)'를 선포하여 2016년부터 2018년까지 3년 간 그동안의 문제점들을 해결하고자 하는 노력을 기울이고 있다. 한국자원봉사의 해는 민간이 주도하고 정부가 지원하는 기본 방향을 바탕으로 진행되고 있다. 현실적으로 3년이란 제한된 시간 동안 많은 활동을 할 수는 없겠지만, 동 기간에 자원봉사에 대한 대중의 인식을 제고하고, 그간의 다양한 사회문제를 해결하기 위한 새로운 모델들을 확산 및 공유하는 동시에, 향후 자원봉사가 가야할 방향을 설정하고 불필요한 정책적 걸림돌을 제거하기 위해 필요한 정책을 제안하는 등 다양한 시도들을 추진 중에 있다.

그 내용은 크게 첫째, 자원봉사 참여문화 확산을 위한 자원봉사 가치 고취 노력, 둘째, 자원봉 
사가 사회문제 해결에 중요한 역할을 할 수 있도록 우리 사회에 시급히 해결해야 할 과제 선정과 과제별 다양한 사례 발굴 및 보급, 영향력 지표 개발, 셋째, 민간 자원봉사 인프라 강화를 위해 기본법 개정, 제 3 차 자원봉사활동 기본계획 수립, 국회자원봉사포럼 발족 및 파트너십 구축, 자원봉사기금 조성 등의 정책과제가 있다. 다음은 "2016-2018 한국자원봉사의 해 가이드 북"에 게재된 사업 내용과 10 대 과제 및 추진배경이다.

\section{제 $\mathrm{I}$ 장}

개

발

협

력

이

슈

|추진배경_지구촌 과제 해결



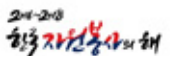

출처: 2016-2018 한국자원봉사의 해 가이드북

특히 한국자원봉사의 해를 계기로 2018년까지 자원봉사자가 해결해야 할 10 대 사회이슈와 과제를 선정하여 사회문제 해결형 자원봉사 모델 사례를 발굴하고 보급하며, 사회적 영향력을 높이기 위한 지표도 개발하여 운영하고 있다. 이 과제들은 국제연합(United Nations, UN)이 2030년까지 세계가 공동으로 해결해야할 과제로 선정한 지속가능개발목표(Sustainable Development Goals, 이하 SDGs)와 맥락을 같이하여 여러 관계자의 워크솝을 통해 선정한 것이다. 
〈그림 8〉 2016-2018 한국자원봉사의 해 10대 과제

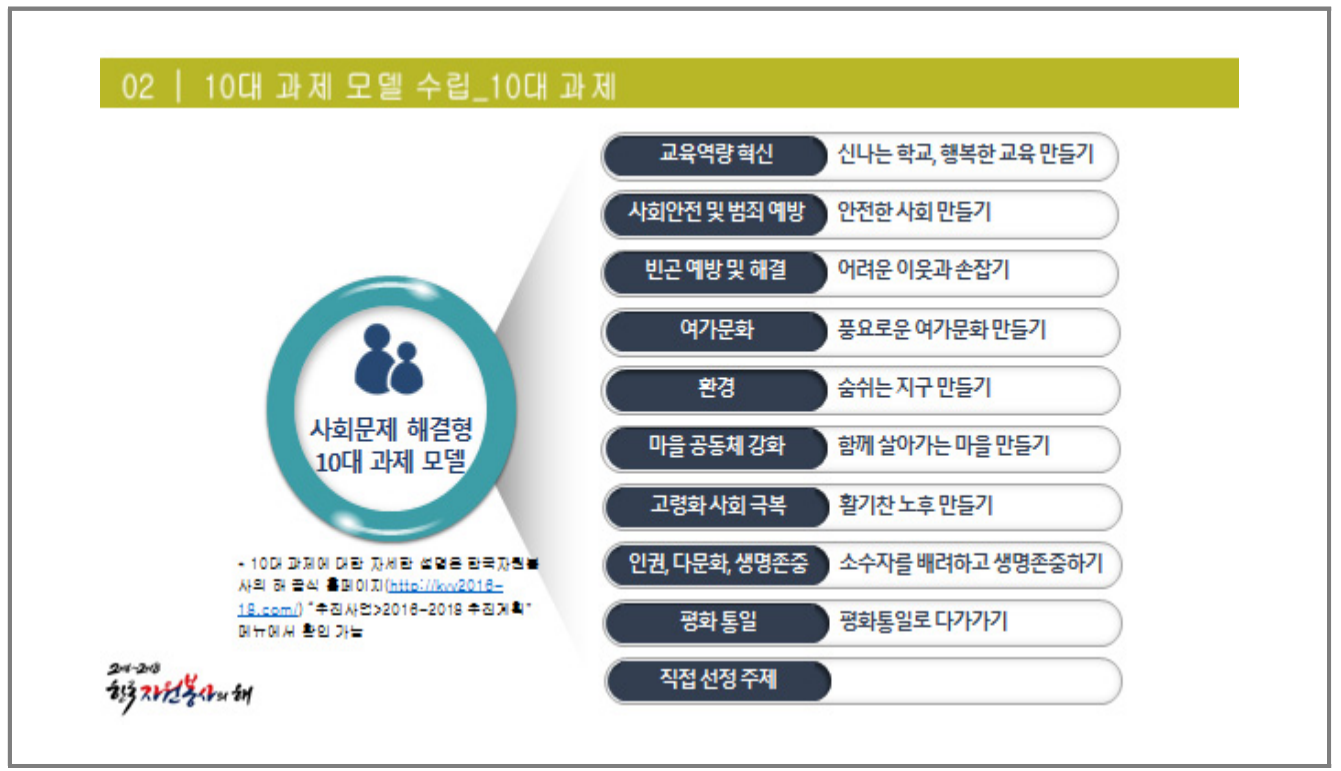

출처: 2016 2018 한국자원봉사의 해 가이드북

〈그림 9〉 2016-2018 한국자원봉사의 해 사업 내용

\section{사업 내용}



02 이애 과제 모델 수립

- 10 대 과저 시민창여헝 모델 발 굴, 보급

- 과세해결영 프로젝트 활성화

- 프로그람 성과운현, 지표개발
03 | 인간 자원폽사인프라 감화

- 자원몽사발전을 위한 정햑 수림 - 자원봉사활동기본법 개장 - 저3사 자원봉사환동 기본계욜 수립 - 국회 자원봉사 모럼 발족 잋 파트너십

- 기금조셩

- 자원몽사진홍기금 조성 연구 및 추진

- 한국자젼몽사의해 사업비 모긍

출처: 2016-2018 한국자원봉사의 해 가이드북 


\section{3. 사회문제 해결로서의 자원봉사}

자원봉사가 지구촌의 심각한 사회·생태문제 해결에 중요한 기여를 할 수 있다는 국제적 인식 하에 SDG 17에서도 SDGs의 효과적인 달성을 위한 혁신적(innovative)이고 변혁적인 (transformative) 파트너십 구축을 위해 자원봉사의 적극적인 역할이 중요함을 강조하고 있다. 이렇듯 한국 사회에서도 자원봉사는 이제 단순히 사회복지 분야에 한정된 서비스를 제공하는 수준을 넘어서 시민주도(citizen-led)로 지역문제를 해결하고 공동체를 회복해나가는 데에 중 요한 역할을 한다는 공통의 인식이 확대되어 가고 있다. 이와 더불어 언론과 자원봉사센터들 또한 사회문제에 초점을 맞추어 사회적 변화를 만들어 가는 다양한 사례와 모델을 발굴하고 확산하는 노력을 진행하고 있다.

\section{제 I 장}

\section{가. 중앙일보 자원봉사대축제}

1994년부터 시작되어 올해로 24 회를 맞고 있는 중앙일보 자원봉사대축제도 사회문제와 관련 된 포럼과 자원봉사 우수 프로그램 사례를 공모하여 보급하고 있다. 동 행사는 매년 새로운 주제와 슬로건을 선정하고 있는데, 그 이유에 대해 중앙일보 시민사회환경연구소 노유진 차장은 다음과 같이 말했다.

“해마다 사회 이슈와 현안을 반영하여 주제와 슬로건을 선정한다. 예를 들면, $\mathrm{IMF}$ 사태 당시의 주제는 '실직자 돕기,' 월드컵을 1년 앞둔 2001년에는 ‘월드컵 과 함께 내 고장 가꾸기,' 2002년에는 ‘세계로 열린 시민정신,' 2007년은 ‘지식 재능봉사로 만드는 나눔공동체,' 2008년에는 '새로운 이웃과의 소통, 다문화 자 원봉사' 등을 선정하는 식이다.” (한국중앙자원봉사센터 웹진 49호, 「전국자원 봉사대축제 20년의 회고」인터뷰에서 발췌|10)

동 행사는 주제적합성, 실행 완성도 및 지속가능성, 문제 해결 및 복합 정도 차별성과 혁신성 등의 심사기준으로 우수프로그램을 선정, 모델을 확산하는 노력을 기울이고 있다. 대축제와 아울러 시대에 맞는 주제로 특별 포럼도 하고 있다. 2016년에는 한국자원봉사협의회가 진행하 고 있는 '2016-2018 한국자원봉사의 해'와 그 흐름을 같이하여 '자원봉사로 어떻게 사회혁신을 이룰 것인가?'라는 주제로 진행하였다.

10) 노유진 중앙일보 시민사회환경연구소 차장/연구위원의 인터뷰 전문은 한국중앙자원봉사센터 블로그에서 확인할 수 있다. (http://vc1365.tistory.com/653) (접속일: 2017.4.16) 


\section{나. 자원봉사센터의 프로그램 공모전을 통한 풀뿌리 조직 역량 강화}

몇 년 전 자살문제가 심각했을 때, 서울시의 여러 자원봉사센터들과 풀뿌리 민간단체들은 ‘자살예방, 생명존중'이라는 큰 사회적 이슈를 중심으로 3 년 간 다양한 자원봉사활동을 전개하 였다. 그 결과 자살 고위험군 청소년들과 노인들에게 희망편지 쓰기, 집단상담 등 자살충동을 예방하는 노력을 기울여 창의적이고 효과적인 대안을 만들어 내기도 하였다. 이 외에도 다문화 와 자원봉사, 기후변화와 자원봉사, 공동체 회복과 자원봉사 등 해결해야 할 사회문제를 선정하 여 지역의 풀뿌리 조직들이 다양한 자원봉사 아이디어를 공모전에 내고, 이를 실천하는 과정에 교육과 슈퍼비전(supervision)을 제공하면서 풀뿌리 조직 자원봉사자들의 역량 강화 노력을 기울이고 있다.

\section{다. 자원봉사의 사회적 영향력 지표 개발 및 보급}

아울러 자원봉사의 사회적 영향력에 대한 관심 또한 높아지고 있다. 이로 인해 투여 대비 효과성과 이를 넘어선 사회적 영향력에 대한 관심을 바탕으로 지표 개발과 영향력(impact) 측정에 대한 다양한 노력이 이루어지고 있는 실정이다. 자원봉사단체 및 센터, 기업 등이 기존의 수적인 산출(vertical output)만으로는 성과를 측정하는 데에 한계가 있음을 인지하고, 이를 해결하기 위해 적절한 지표를 개발하는 노력도 기울이고 있다. 그러나 시대의 변화에 발맞추어 지표 또한 적절하게 변화되어 나가야 하며, 실제 현장에 적합한 형태로 실무 차원에서 활용할 수 있는 쉬운 용어로 보다 정리해나가야 하는 등의 과제들을 안고 있다.

서울시자원봉사센터는 2013년 '자원봉사활동의 사회적 영향력 측정지표 개발'11)에 대한 연 구(이란희 외, 2013)를 실시함으로써, 기존의 자원봉사에 투입되는 인원 및 시간 등 실적 중심의 성과평가에 치중하였던 것을 자원봉사활동 및 프로그램의 사회적 영향력을 측정하는 기준을 마련하여 실질적인 성과 측정을 시도하였다. 동 분석을 위해서는 자원봉사자(Volunteer), 조직 (Organization), 사회(Society)로 구성된 3개 영역을 바탕으로 하는 VOS모델을 사용하고 있으며, 동 모델은 VOS 3 개 영역에 대한 11 개 평가 항목, 69 개 지표로 개발되어, 자원봉사자가 각각의 영역에 대해 어떠한 영향을 미쳤는지를 평가하는 지표로 구성되어 있다. 세부 평가는 자원봉사활동 후 자원봉사자의 대인관계가 개선되었는지, 행복도가 증가하였는지, 조직에 대한 지역사회의 인식과 평판이 좋아졌는지, 그리고 안전하고 건강한 지역사회 만들기에 도움이

11) 서울시자원봉사센터, 2013 년 한국자원봉사문화수행(한양대 제 3 섹터연구소 이란희 박사, 도움과 나눔 이원규 부대표 등)이 자원봉사자, 조직, 지역사회 분야의 변화를 측정하는 질문을 개발하였다. 
되었는지 등에 대해 전후 평가로 측정한다.12)

‘2016-2018 한국자원봉사의 해’에서도 자원봉사의 사회적 영향력 지표를 만들어 보급하고 있다. 자원봉사 프로젝트가 지녀야 하는 특성으로 과정 지표 3단계에서 혁신성, 시민주도성, 협력성의 3 가지에 주목하여, 사회적 문제의 파악과 정립, 문제 해결과 사회적 혁신에 적합한 자원봉사 프로그램 과정상의 속성을 살펴보고, 결과 지표로는 프로젝트 자체의 확산성과 사회적 변화 2가지에 주목하고 있다(정희선 외, 2016:21-22). 다음 <표 4>는 10대 어젠다 자원봉사프 로젝트 사례 분석을 위한 평가지표이다.

\section{제I 장}

〈표 4〉10대 아젠다 지원봉사프로젝트 시례 분석을 위한 평가지표

\begin{tabular}{|c|c|c|c|c|}
\hline 분류 & 영역 & 개념정의 & 항목 & 지표근거 \\
\hline \multirow{3}{*}{$\begin{array}{l}\text { 과정 } \\
\text { 차원 }\end{array}$} & $\begin{array}{l}\text { 시민 } \\
\text { 주도성 }\end{array}$ & $\begin{array}{l}\text { 프로젝트 기획, 실행, 평가 등 전 과 } \\
\text { 정에 자원봉사자들이 적극적으로 참 } \\
\text { 여하고 책임을 다하였는가를 의미함 }\end{array}$ & $\begin{array}{l}\text { - 자발적 참여 } \\
\text { · 의사결정 태도 } \\
\text { - 역할과 책임 }\end{array}$ & $\begin{array}{l}\text { · ICCS(International Civic and } \\
\text { Citizenship Education } \\
\text { Survey, 2009, 2016) } \\
\text { - 세계자 원봉사협의회(IAVE, } \\
\text { 2003) 자원봉사정신 } \\
\text { - 이은경·오민아·김태준(2015) } \\
\text { 글로벌 시민성 }\end{array}$ \\
\hline & 혁신성 & $\begin{array}{l}\text { 혁신성은 프로젝트가 활동 내용과 } \\
\text { 방식에 있어 기존과 다른 새로운 접 } \\
\text { 근을 했는가를 의미함 }\end{array}$ & $\begin{array}{l}\text { - 새로운 이슈와 대상 } \\
\text { ·창의적인 문제 해결방식 } \\
\text { - 새로운 기술 활용 }\end{array}$ & $\begin{array}{l}\text { - European Commission / } \\
\text { OECD(2015) 사회적 영향력(사 } \\
\text { 회혁신) } \\
\text { - Social Innovation Review } \\
\text { - TEPSIE 사회혁신프레임워크 } \\
\text { 모델(EU) (2014) }\end{array}$ \\
\hline & 협력성 & $\begin{array}{l}\text { 프로젝트의 수행에 필요한 인적, 물 } \\
\text { 적자원들이 적절하게 연계되고 기능 } \\
\text { 하였는가를 의미함 }\end{array}$ & \begin{tabular}{|l} 
- 파트너의 적합성 \\
- 물적자원 활용 \\
- 소통 \\
- 역량발휘
\end{tabular} & $\begin{array}{l}\text { · 이명신 외(2015) 섹터 간 파트 } \\
\text { 너십 프레임워크 } \\
\text { - Tennyson(2011) 섹터 간 파 } \\
\text { 트너십 툴 }\end{array}$ \\
\hline \multirow[t]{2}{*}{$\begin{array}{l}\text { 결과 } \\
\text { 차원 }\end{array}$} & $\begin{array}{c}\text { 사회적 } \\
\text { 변화 }\end{array}$ & $\begin{array}{l}\text { 프로젝트 수행 결과 이해관계자들의 } \\
\text { 삶의 질이 향상되고 사회 환경이 변 } \\
\text { 화되었는지를 의미함 }\end{array}$ & $\begin{array}{l}\text { - 사회문제 해결 기여 } \\
\text { · 삶의 질 및 지역사회 변화 } \\
\text { ·법/제도 변화 } \\
\text { · 지역사회 인식 향상 } \\
\text { · 참여자 역량 향상 }\end{array}$ & \multirow{2}{*}{$\begin{array}{l}\text { 이란희 외(2013) 자원봉사 사 } \\
\text { 회적 영향력 지표 } \\
\text { 김용득 외(2010) 사회공헌 성 } \\
\text { 과지표 } \\
\text { UWA 성과관리모델 } \\
\text { Social Value 측정평가모델 } \\
\text { 아쇼카 영향력 측정모델 }\end{array}$} \\
\hline & 확산성 & $\begin{array}{l}\text { 프로젝트가 다른 지역이나 이슈로 } \\
\text { 적용과 보급이 용이한지를 의미함 }\end{array}$ & · 보급가능성 & \\
\hline
\end{tabular}

출처: 정희선 외 (2016)

12) 서울시자원봉사센터 블로그를 참조하기 바란다. (http://svc1365.tistory.com/969) (접속일: 2017.4.16) 


\section{4. 계층별 자원봉사}

\section{가. 청소년}

1995년 ‘5.31 교육개혁’의 일환으로 청소년 자원봉사활동 의무화가 실시되었다. 학생 자원봉 사활동의 제도화 과정에서 자원봉사로 유인하기 위하여 '시간 수 적립'이라는 인센티브를 제공 하였는데, 이러한 인센티브가 오히려 자원봉사를 ‘점수 따기’ 위한 것으로 인식하게 만드는 문제를 초래하고 있다. 학교도 지역사회도 준비가 되어 있지 않은 상태에서 자원봉사활동 거리 를 찾기 위해 학생들이 갑자기 쏟아져 나온 상황은 많은 문제를 낳았다. 행정자치부의 ' 1365 자원봉사포털’과 여성가족부의 청소년을 위한 ‘두볼’등 자원봉사 정보를 알려주는 시스템에도 불구하고 아직 청소년들이나 학부모들이 적합한 활동거리를 찾는 데에 적지 않은 어려움이 존재하는 것이 사실이다. 이러한 어려움 속에서도 교육청과 한국청소년진훙원, 시도 청소년활동 진흥센터에서는 청소년 자원봉사를 지원하기 위해 노력을 기울이고 있다. 지역 자원봉사센터에 서도 자원봉사자들을 청소년 교육 강사 혹은 코치로 양성하여 자원봉사 기본 교육과 활동 프로 그램 개발, 정보제공 등의 노력을 기울이고 있으며, 청소년 자원봉사가 자기주도적으로 진행될 수 있도록 안내하고 있다.

\section{나. 대학생}

대학생들의 자원봉사는 대학생 스스로 지역의 문제를 발견하고 문제 해결을 위한 봉사활동 프로그램을 직접 기획·실행하는 과정을 통해 시민으로서의 덕성과 문제 해결력, 리더십을 키울 수 있다는 점에서 매우 중요한 활동으로 인식되어 전국 거의 모든 대학교들이 대학생 자원봉사 프로그램을 운영하고 있다. 대학의 사회봉사는 교육, 연구와 더불어 3 대 대학 기능 중 하나이다. 대학생들이 공공(公共) 및 지역사회 봉사활동을 통해 시민적 참여에 관한 가치관과 봉사기술을 개발, 장려하는 데 일조하고자13) 1996년 대학사회봉사협의회(대사협)가 설립되었고, 지금은 거의 모든 대학이 자원봉사학점 이수제도 및 자원봉사 프로그램을 운영하고 있다. 대학생들이 자원봉사활동의 중요성을 인식하고 글로벌 시민의식을 가지고 사회로 나올 수 있도록 많은 해외봉사활동 기회가 제공되고 있다. KOICA와 지자체, 국제개발민간협의회 소속 민간단체와 기업 등이 이러한 기회 제공의 광범위한 통로 역할을 하고 있다. 많은 시민단체와 자원봉사단체 들, 대학들이 자원봉사센터 운영과 자기주도적 활동 기회 제공 등 학생들의 유의미한 봉사활동 을 위해 기회를 제공하고 있으나 아직 많은 대학생들이 자원봉사활동을 청소년 시절 경험한

13) 대학사회봉사협의회 창립발기문에서 일부 발췌하였다. 동 협의회의 창립발기문 전문은 협의회 홈페이지에서 확인가 능하다. (http://www.kucss.or.kr/page/profile)（접속일: 2017.4.16) 
의무 봉사활동의 연장선상으로 인식하거나 소위 경력 쌓기를 위한 부분으로 인식하는 경우가 많다. 봉사활동의 기본 정신에 부합하는 형태로 대학생 자원봉사 활동을 이끌어가기 위해서는 앞으로 개선해나가야 할 과제가 많다고 할 수 있다.

서울시자원봉사센터에서는 기획봉사단과 홍보봉사단을 꾸준히 운영하고 있다. 대학생들은 이를 통해 팀을 이루어 스스로 사회문제를 발굴하고 문제 해결에 대한 아이디어를 내서 직접 실행하고 평가하는 경험을 하고 있다. 이들은 이 과정에서 많은 시행착오를 겪으며 이를 통해 성장의 기회를 갖게 되기도 한다.

제I장

\section{다. 은퇴자}

1 차 베이비붐 세대의 대대적인 은퇴에 이어 2 차 베이비붐 세대가 은퇴할 예정이다. 조기 은퇴를 하고 사회로 나오는 은퇴자들의 제 2 의 인생설계는 국가적으로 큰 과제가 되고 있다. 자원봉사센터들은 공공업무, 청소년 자원봉사활동 안내자 등 은퇴자들을 위한 자원봉사활동 기회를 만들어 제공하고 있다. 한국자원봉사문화는 '앙코르유 센터(Encore-U)'를 설립하여 은퇴자들이 청소년들의 진로체험학습 멘토(mentor) 역할을 하는 봉사활동 프로그램을 안내하 고 있다. 또한 50세 이상을 위한 교육 및 취업, 창업 등을 비롯한 다양한 사회활동을 지원하기 위해 서울시가 설립한 ‘50+ 캠퍼스’에서는 50세 이상 은퇴자들을 대상으로 일자리, 평생교육(인 문학 등) 등 다양한 교육과 함께 자원봉사와 사회공헌에 관한 강좌를 개설하여 제공하고 있다.

「제2차 자원봉사진흥을 위한 국가기본계획」에 명시되어 있는 '생애주기별 자원봉사 확대' 부문에서도 특히 은퇴자들을 위한 자원봉사 기회 제공을 중요한 과제로 삼고 있다. 정부 각 부처와 기업들이 제공하는 기회도 많고 비영리 영역에서도 다양한 기회를 제공하는 노력을 기울이고 있지만, 아직 이들의 재능과 관심사, 사회·경제적 여건에 적합한 자원봉사 기회를 만드는 일은 큰 과제로 남아 있다.

\section{라. 이주민}

어린이, 노인, 이주여성과 이주노동자, 장애인 등 사회적 취약계층으로 자원봉사활동의 대상 으로만 여겨지던 이들의 자원봉사 참여 사례가 나타나고 있다. 자원봉사활동을 통해 사회에 기여함으로써 자존감을 높이고 사회의 한 일원으로서 공동체성을 강화하는 역할을 하고 있다. 자원봉사활동 현장에서는 이들의 욕구를 반영하여 도움을 받는 사람과 주는 사람의 경계를 허물고 모두 함께 참여하고 경험할 수 있는 자원봉사 프로그램을 만들어내고 있다. 
특히 이주노동자들이 짬을 내어 지역사회 자원봉사단체에 가입하거나 국가별로 자원봉사 모임을 조직하여 자원봉사 경험을 하는 사례가 늘고 있고, 이렇게 경험을 한 이들이 귀국하여 자신의 나라에서 자원봉사단체를 창립하여 운영하는 사례들도 종종 생기고 있다. 예를 들어, 네팔(Nepal)의 네코스(Nepal Korea Culture Exchange \& Social Organization, NEKOS) 라는 자원봉사단체가 있다. 한국에서 5 년간 이주노동자로 근무하며 시흥시 자원봉사센터를 통해 네팔 이주노동자 자원봉사단을 만들어 활발한 활동을 한 네팔 현지민이 자국으로 돌아가 한국 네코스와 나란히 설립한 단체이다. 이 단체는 네팔 지진 때 복구 노력과 집을 짓는 활동 및 지역을 깨끗이 하는 노력을 캠페인과 함께 진행해 현지 주민들의 호응을 얻고 있다.

\section{V. 아태지역 자원봉사}

\section{SDGs 실현을 위한 자원봉사}

아시아 태평양 지역 각국에서는 지속가능개발목표(Sustainable Development Goals, 이하 $\mathrm{SDGs}$ ) 이행 관련 단체들과 자원봉사단체들이 SDGs와 자원봉사에 대한 콘퍼런스, 워크솝, 사례 발굴, 직접적인 실천 등 다양한 노력을 기울이고 있다. 태국의 경우 지난 2016년 9월, ‘SDGs와 자원봉사(Volunteerism: A significant contribution to SDGs)'라는 주제로'제 2회 전국 콘퍼런스(2nd National Conference on Volunteerism)'를 개최함으로써 국제연합봉 사단(United Nations Volunteer, 이하 UNV)과 일본, 홍콩, 한국을 비롯한 9개국에서 발표자를 초청하여 SDGs 달성을 위한 각국의 자원봉사 실천 노력 방안을 함께 공유하기도 했다. 또한 대만에서는 청년들과 함께 '지속가능발전을 위한 새로운 글로벌 파트너십 구축(Building up a new global partnership for Sustainable Development)'란 주제로 한국의 전문가를 초청하여 워크솝을 진행하며 청년들이 혁신적인 사회문제 해결 실천 사례들을 접해보는 연수도 진행하였다.

직접적인 실천의 한 예로, 방콕 부근 촌부리 주(Chonburi Province)의 에코빌리지(Eco Village)는 척박한 토지를 일구어 생태계를 살려내고 그 땅의 산출물로 집도 짓고 음식과 생필 품들을 만들어 사용하는 등의 노력을 하고 있다. 또한 숙박시설 운영방식을 비롯해 주민들의 일상에서도 자급자족 경제방식을 최대한으로 준수하고 자원은 최소한으로만 사용하는 등의 노력을 실천하고 있다. 에코빌리지는 지속가능한 자급자족 경제방식을 후대에 교육하기 위해 아이들을 위한 기본 교육과정뿐만 아니라 대학 및 대학원 과정을 개설하여 운영하고 있다. 
아울러 지속가능한 농업 기술, 영어, 예술 교육 등과 관련한 교육봉사를 실시하는 동시에 홈페이 지, 페이스북 운영 등과 같은 다양한 온라인 홍보활동 또한 전개하고 있으며, 이러한 활동에 많은 자원봉사자가 적극적으로 참여하고 있다.

제I 장

자원봉사문화 활성화 사업'은 개발도상국가의 자원봉사 인프라 지원 및 역량 강화사업의 좋은 예가 될 수 있다. 이는 「자원봉사진흥을 위한 국가기본계획」 5 번째 정책 영역의 두 번째 과제 세부 목표인 '자발적이고 주도적 발전을 위한 개도국의 자원봉사 문화지원'의 달성에 기여 하는 사업으로, 2011년 개최된 부산세계개발원조총회(the 4th High Level Forum on Aid Effectiveness, HLF-4) 이후 지역주민의 주체적이고 적극적인 국제 개발 협력 분야 참여를 장려하기 위한 효과적인 방법론 개발의 필요성에 기반을 두고 진행된 사업이다.

동 사업 운영은 2013년 타당성조사(feasibility study)를 시작으로, 2014년 '베트남 자원봉 사지도자 역량 강화’를 위한 현지교육 및 ‘베트남자원봉사센터(Vietnam Volunteer Center, $\mathrm{VVC}$ ) 인프라 구축'을 위한 관리자 초청 연수를 시행하고, 2015년에 '베트남 자원봉사지도자 현지교육'을 실시하는 방식으로 진행되었다. 특히 2014년에는 베트남자원봉사센터 관리자 5명 을 초청하여 2 주간 정부와 기업, 중앙·광역·지역 단위의 자원봉사센터, 시민단체 및 자원봉사 현장을 방문하고 자원봉사 체험 기회를 가졌다. 또한 한국자원봉사 인프라의 발전과정과 한계 점, 운영 노하우, 자원봉사조직 운영 노하우, 프로그램 개발, 교육기획 등에 대한 다양한 연수기 회를 가졌다. 아울러 참가자들이 사전에 개별 연수의 목적과 연수를 통해 얻고 싶은 점 등을 연수계획서로 작성하고 연수과정 동안 현장학습을 통해 배운 점, 베트남 현지에 대한 적용 희망사항, 추후 학습 희망사항 등을 일지로 작성 및 평가하도록 했다. 이처럼 체계적으로 연수를 진행한 결과, 참가자들은 베트남 자원봉사 인프라 발전을 위한 시사점과 한계점, 적용점 등에 대해 다양한 아이디어를 얻어갈 수 있었다(한국자원봉사협의회, 2014).

\section{3. 지역 청년들의 성장을 돕는 시례}

라오스 청년들이 지역사회를 이해하고 지역발전을 위한 주체로 성장하도록 지원한 사례도 있다. 이선재 유네스코한국위원회 전 대외협력본부장은 2000년대 초부터 교류해온 라오스 왕위 앙(방비엥) 마을에 2007년 '청소년센터(Youth Center)'를 설립하여 청소년들의 성장을 지원하 
고 있다. 동 센터의 경우 현지 청소년들을 직접 운영에 참여시키며 지역의 일꾼으로 성장하게 함으로써, 현지민의 주인의식(ownership) 강화에 기여하고 있다. 지금은 인근 5개 마을 주민들 의 요청으로 주민들과 함께 5 개 마을에 청소년센터를 추가 설립하고 푸딩댄 청소년센터 (Phoudindaeng Youth Center)에서 성장한 청년들이 자신들의 학습 내용을 바탕으로 마을의 청소년 활동을 지원하고 있다고 한다. 이선재 전 대외협력본부장의 글을 다음과 같이 인용한다.

"나는 라오스 왕위앙에 있는 푸딘댕 청소년센터에서 자원 활동을 한다. 2007 년에 문을 연 센터는 라오스 안팎으로 꽤 유명하다. 지역에서 오랜 준비기간을 거쳐 설립했고, 지금은 청년들이 어른 없이 스스로 운영하는 사례로 많이 알려져 있다. 요즘에는 이 청년들이 푸딘댕 센터를 운영할 뿐만 아니라 왕위앙 지역 여러 마을의 청소년 활동을 지원하거나 청소년센터 설립 일을 돕고 있다.”(ODA WATCH 뉴스레터 83호, 2013)14)

$\mathrm{UNV}$ 의 전략적 목표15) 중의 하나 또한 지역 청년들의 성장(growth)과 역량 강화 (capacity building)인데, 이러한 점에서 동 센터의 활동은 라오스 현지에서 장기간에 걸쳐 봉사활동을 실천하면서 현지민의 실제 변화와 성장을 일구어내는데 지속적으로 기여하고 있다고 할 수 있다.

\section{VI. 국내봉사활동 운영 시사점과 해외 봉사활동과의 파트너십 강화를 위한 제언}

국내자원봉사 운영 경험을 비추어보았을 때, 크고 작은 문제 해결을 위한 궁극적인 지향점은 사람(people)의 변화이자 사회(society)의 변화이다. 이를 위해 사람을 어떻게 발굴하여 성장 시키고, 어떤 프로그램으로 이러한 변화의 과정을 추진할 것이며, 이를 뒷받침하기 위한 인프라 및 정책 기반은 어떻게 구축되어야 하는지가 중요한 관건이 된다. 이에 따라, 이번 장에서는 $\mathrm{KOICA} \mathrm{WFK} \mathrm{사업과} \mathrm{해외봉사활동의} \mathrm{파트너십} \mathrm{강화를} \mathrm{위해서는} \mathrm{어떠한} \mathrm{점을} \mathrm{고려해야할지에}$ 대해 사람, 프로그램, 인프라 및 정책 등 3 가지 측면으로 나누어 제언하고자 한다.

14) 이선재 전 대외협력본부장의 '라오스 방비엥 청소년센터' 설립 및 활동과 관련하여 보다 자세한 사항은 'ODA WATCH 뉴스레터'의 “이선재, 라오 이야기 2. 누가 지역을 지키나? - 세상물' 좀 먹어본 청년들”을 통해 확인 가능하다. (http://www.odawatch.net/?mid=articlesth\&page=35\&document_srl=38427) (접속일: 2017.4.15)

15) UNV의 운영 전략은 UNV 홈페이지에서 확인 가능하다. (https://www.unv.org/about-unv) (접속일: 2017.4.15) 


\section{1. 사람 (people)}

사람의 성장은 현지인의 성장과 봉사자의 성장, 실무자/지도자의 성장으로 나누어 생각해볼 수 있다.

제 I 장

세계자원봉사협회의 전체 회원국 구성을 보면, 6 개의 지역 중 아시아. 태평양지역에 가장 많은 국가수가 분포되어 있다. 대상 국가들 중에는 호주, 중국, 미얀마, 베트남, 라오스, 필리핀 등과 같이 우리나라 봉사자들이 자원봉사를 위해 활동하는 국가들도 다수이다. 또한 아태지역 각국에 서 IAVE 아태지역 자원봉사 대회(IAVE Asia-Pacific Regional Volunteer Conference)가 개최될 경우, 개발도상국 내 자원봉사단체 지도자들이 참여하여 자신들의 자원봉사활동 경험 및 노하우, 애로사항 등을 다른 나라의 자원봉사 지도자들과 함께 공유함으로써 상호학습의 기회로 삼고자 노력하고 있다. 개발도상국의 경우, 대부분 정부 지원이 부족하여 자원봉사 인프 라 자체가 잘 갖춰지지는 않았으나 이에 비해 민간 차원에서는 자원봉사활동의 활성화를 위해 다각적인 노력이 기울여지고 있다. 이로 인해 개도국 현지 봉사단체들 또한 봉사활동 전문가로 서의 실무역량을 지속적으로 쌓아가고 있다.

2011년 경남 창원에서 제 13차 아태지역 자원봉사대회(13rd IAVE Asia-Pacific Regional Volunteer Conference)가 개최되었을 당시, 라오스의 참여발전훈련센터(Participatory Development Training Center, 이하 PADECT) 단체 창립자인 솜밧솜폰(Sombath Somphone)16) 대표가 연사로 초청되어 라오스의 전통과 자연을 파괴하지 않는 지속가능한 발전 달성 방안에 대해 발표하였다. 국민들의 정신과 환경, 행복을 고려한 개발 활동과 유기농법 사용, 전통과 공동체를 지키기 위한 세대 간 교류 등에 초점을 맞추어 자체적으로 모델을 구축하 고 이행해나가는 PADECT의 모습이 당시 참가자들로부터 높은 평가를 받았다. 아울러 PADECT에서 인큐베이팅하여 설립된 농촌개발기관(Rural Development Agency, RDA) 은 현재 세계자원봉사협회의 회원국 중 하나인 라오스를 대표하는 단체로 활동하고 있다. 세계 자원봉사협회의 회원국들과 대표들은 활동 현황을 보면 상호간의 장점과 각자의 시행착오를 통한 경험을 서로 공유하고 학습하는 방식으로 운영되고 있으며, 이는 일방적으로 경험과 지식 을 전달하는 단순한 방식이 아닌 쌍방의 교류 방식이라고 할 수 있다.

16) 라오스 참여발전훈련센터 창립자인 솜밧솜폰 대표에 대한 상세한 사항은 다음을 참고하기 바란다. (https:// en.wikipedia.org/wiki/Sombath_Somphone) (접속일: 2017.4.18) 


\section{2) 현지의 자발적 노력을 지원}

'ODA Watch 뉴스레터'의 '미얀마 지역개발 활동가들, 한국시민사회를 만나다'편을 통해 미얀마 지역의 개발활동가들로부터 한국의 공적개발원조(Official Development Assistance, 이하 $\mathrm{ODA}$ )가 어떠한 방향으로 나아가야할지에 대한 제언을 살펴볼 수 있다. 다음은 동 편에 소개된 미얀마 활동가 2 인의 인터뷰 내용이다. 한국을 찾은 미얀마 활동가 아웅 니우(Aung Niwoo) 씨의 활동 경험은 한국의 ODA가 어떤 방향으로 가야 할지를 현지 사람들의 입장에서 말해주고 있다.

“한국의 시민단체들이 단순히 미얀마를 돕겠다는 생각으로 또는 단체의 사업 실적을 달성하기 위한 목적으로 미얀마에 들어오지 말고 미얀마 주민과 함께 한다는 생각으로 미얀마에 들어와서 활동해야 한다. 여러분이 그들보다 모든 면에 서 낫다는 생각을 버려야 한다. 그들이 어찌 보면 정신적으로 더 풍요롭고 공동체 적 가치를 중요하게 여긴다. 그들이 여러분보다 서로를 더 이해하고 배려한다. 여러분의 방식대로, 여러분의 생각대로 그들을 바꾸려는 생각을 버려야 한다." (ODA WATCH 뉴스레터 83호, 아웅 나우(Aung Niwoo) 활동가 인터뷰 내용 에서 발췌)

“학교 건물 몇 동, 우물 몇 개 등 가시적인 인프라 지원이나 일회적인 지원은 성공의 기준이 될 수 없다. 미얀마 주민 스스로가 문제를 해결할 수 있도록, 지속적으로 미얀마 지역사회와 주민들의 역량 강화를 지원하고 미얀마의 시민사 회와 협력·연대할 필요가 있다.”(민민(Myint Myint), 'ODA Watch 뉴스레터 제83호 상의 인터뷰 내용에서 발췌)

이러한 내용에 기반하여 보았을 때, $\mathrm{KOICA}$ 의 WFK 사업이 봉사활동 대상 현지민들이 자발적으로 변화를 유발하기 위해 어떻게 노력할 수 있는지를 파악하고 이들의 역량 강화를 지원하는 활동에 보다 초점을 맞추어 운영한다면, 이것이야말로 장기적인 차원에서 보다 지속가 능하고 높은 효과를 낼 수 있는 방안이 될 수 있을 것이다. 따라서 아직 공동체를 통해 많은 문제를 해결하고 있는 곳에서의 자원봉사는 어떤 모습으로 접근 및 실시되어야하는지에 대한 지속적인 논의와 모델 구축의 노력이 필요하다. 아울러 봉사활동 사업 운영에 있어 현지민들의 자발적인 참여(voluntary participation)를 효과적으로 장려 및 지원하기 위해서는 해당 지역 의 현지민들로부터 사업 운영의 접근 및 방식에 대해 직접적인 의견을 듣고 도움을 요청하는 자세가 필요하리라 생각한다. 


\section{3) 자원봉사 참여경험이 있는 외국인노동자들의 현지 단체 설립지원}

아울러 기존에 한국에서 자원봉사에 참여한 바 있는 개인 차원의 경험이 바탕이 되어 추후 개발도상국의 현지 봉사활동 단체 설립으로 이어지는 사례도 있다. 가령 네팔의 네코스, 미얀마 의 미얀마봉사단센터(Myanmar Volunteer Community Center, MVCC) 모두 외국인 노동 자 신분으로 한국에 거주하며 자원봉사활동에 참여한 경험이 있는 현지민들이 본국에 귀국한 후 설립한 봉사활동단체이다. 동 현지 단체들의 경우 자체적으로 운영하는 과정에서 한국 내 멘토들로부터 지속적으로 자문을 지원받음으로써 단체의 운영 방향을 설정하고, 현지에서 실제 단체를 운영할 때 발생하는 문제점 및 애로사항에 대해서도 자문을 구하는 등 지속적인 교류 관계를 유지하고 있다. 이렇듯 국내 자원봉사단체 및 자원봉사센터들이 외국인 노동자들의 참여를 도모하는 자원봉사 프로그램을 운영하면서 자연스럽게 한국의 자원봉사활동을 경험할 기회를 제공함에 따라, 한국 봉사활동단체 운영 방식의 개발도상국 현지 확산 및 전수에 기여하 고 있다고 볼 수 있다.

\section{4) 은퇴자들의 역할}

네팔 네코스의 경우 네팔 현지인들과 네트워크를 맺어 필요한 자원을 연계하고 있다. 자원봉 사활동 프로그램의 기획 및 현지 지도자 교육 담당자의 구성을 보면 자원봉사단체 및 센터 소속 실무자들뿐만 아니라 비영리조직(Non-Profit Organization, NPO) 운영 실무 경험이 있던 은퇴자들 또한 포함된다. 유네스코한국위원회 이선재 전 대외협력본부장의 경우도 은퇴 후 지구촌 귀농을 한 사례로 알려져 있다. 이와 같이 국내에서 자원봉사를 경험한 은퇴자들이 오랜 현장 경험 및 노하우와 함께 은퇴 후 비교적 시간 여유가 충분히 확보된다는 장점을 활용하여 해외 현지민들의 자원봉사단체 설립 및 운영을 위한 자문을 제공하는 등의 활동을 통해 현지센터의 지속적인 성장을 돕는 역할을 한다면 사업의 효과성이 높을 것이다. 또 다른 일례를 보면, 한국에서 한국어 교사로의 재직 경력 및 국내 청소년과 외국인 노동자를 대상으로 한 한국어 봉사활동 경험이 있다고 가정할 경우, 이러한 경험을 살려 은퇴 후 코이카 시니어봉사단원 활동을 통해 현지 학생들에게 한국어를 교육하는 봉사에 참여할 수 있다. 이렇듯 은퇴자들의 적극적인 국내외 봉사활동 참여는 해외 현지민들이 스스로의 역량을 개발 하고 보다 나은 삶을 꿈꿀 수 있도록 하는데 기여한다. 뿐만 아니라 국내에서 외국인 노동자들 을 대상으로 봉사활동을 할 경우에도 추후 이들이 본국으로 돌아가 한국에서의 봉사교육 이수 경험을 바탕으로 새로운 형태의 자원봉사활동으로 이어갈 수 있도록 하는데 크게 기여할 수 있는 것이다. 


\section{나. 자원봉사자들의 성장을 위한 국내 자원봉사단체/센터들과의 파트너십: 자원봉사 기획, 실무 경험, 자원봉사자 모집}

서울시 자원봉사센터에서는 청소년, 대학생들이 하나의 팀을 이루어 직접 사회문제를 발굴하 고 스스로 문제 해결 과정을 기획·진행하는 방식의 '기획봉사단 프로그램'을 운영한다. 이러한 방식의 청소년, 대학생 대상 봉사단 프로그램은 청소년 및 대학생이 직접 봉사활동을 기획하고 운영함으로써 문제 해결력과 리더십을 강화하는 등 스스로도 많은 성장을 경험할 수 있다는 점에서 높이 평가할 수 있다. 특히 청소년 및 대학생을 대상으로 하는 봉사활동 프로그램 운영은 ‘준비-실행-평가와 반성-인정과 축하’ 의 봉사학습(service-learning)적 개념으로 접 근하는 것이 중요하다. 국내에서는 학생들이 바쁜 학업 일정으로 인하여 봉사활동 프로그램 참여 시 봉사활동적 접근을 하는데 충분한 시간을 할애하는 것이 쉽지 않다. 하지만 자원봉사센 터에서 동아리를 조직하여 6 개월-1년 이상 장기적인 활동을 할 경우, 기관 차원에서 보다 체계적으로 봉사학습적 접근방식에 따라 봉사활동이 운영되도록 관리하기 때문에 이러한 한계 를 다소 보완할 수 있다. 특히 해외봉사활동의 경우에도 봉사학습적 접근방식을 통해 준비 가능한데, 가령 서울시자원봉사센터가 운영하는 '동행 프로젝트'에 참여하는 대학생 자원봉사 자들의 경우, 2 주간의 해외봉사를 시작하기 전에 먼저 2 달 동안 사전준비를 시작하고, 봉사활동 종료 후 한 달 간 사후평가 및 인정 등의 프로세스에 맞추어 봉사활동 상황을 정리하여 보고서 로 발간한다. 이러한 일련의 프로세스는 서울시 자원봉사센터의 관리 하에 스스로 기획하여 운영하게 된다.

아울러 국내 자원봉사단체와 센터들은 청소년, 대학생뿐만 아니라 지역 주민들 또한 자원봉 사자로 활동할 수 있도록 하는 프로그램을 운영하고 있다. 이는 지역주민들을 자원봉사자로 발굴하고 조직화하여, 스스로 의미 있는 프로그램을 기획 및 운영하도록 함으로써 본인이 속한 지역의 중요한 구성원이자 지도자로 성장해나갈 수 있도록 지속적으로 지원하는 형태이다. 이러한 프로그램 운영과 관련한 노하우는 상당 수준으로 축적되어 있는 실정이다. 해외봉사활동 으로 파견되는 사람들을 훈련하는 과정에 이러한 노하우가 접목될 수 있다면 파견 봉사자들의 성장에 도움이 되리라 생각한다. 또한 이미 국내 곳곳에 역량이 성장해 있는 자원봉사자들이 많이 있으므로 해외봉사단원 모집 시 자원봉사단체와 센터들을 통해 모집을 하면 보다 경험이 축적된 양질의 봉사자들을 만날 수 있을 것이다. 국내 자원봉사단체와 센터들 간에 긴밀한 파트너십이 필요한 이유이다. 


\section{다. 실무자/지도자들의 성장을 위하여: 기본 철학을 배우는 해외자원봉사 관련 업무 종사자 연수}

서울시자원봉사센터에서는 지난 2013년부터 2016년까지 총 3년간 자원봉사단체 및 센터 소속 활동가, 관련 실무자 약 40여 명을 대상으로 라오스의 푸딩댄 청소년센터에서 실무 역량 강화 연수사업을 운영한 바 있다. 동 연수사업에 참여한 어떤 실무자는 연수활동 종료 후 동 연수 프로그램을 통해 '봉사 사업 운영 기술을 배우러 갔다가 철학을 배우고 왔다’고 평가하였다. 이와 같이 동 연수 프로그램 참여를 통해 자원봉사란 무엇이며, 지역사회란 무엇인지, 그리고 우리가 살고 싶은 미래는 어떠한 모습인지 등에 대해 스스로 질문을 던지고 자신 또한 돌아보는 계기가 된 것이다. 아울러 동 연수기회를 통해 한국의 발달된 수준을 현지민들과 나누러 갔다가 오히려 공동체가 살아 있는 오래된 미래의 모습을 하고 있는 라오스를 접하게 됨에 따라 연수 참여를 통해 진정한 변화와 발전이 무엇인지에 대해 몸소 경험하고 배울 수 있는 계기로 작용하 였다고 평가된다. 동 프로그램 종료 후에도 연수 참여자들은 자발적으로 라오스 청년 리더들의 성장을 지원하기 위한 바자회와 모금 등의 노력으로 연계하고 있다. 또한 현장에서 자원봉사자 들과 후배 실무자들의 성장을 돕는 멋진 실무자들로 변화·성장해 나가고 있다.

이런 수준의 연수라면 국내외 자원봉사활동 안내를 할 수 있는 활동가들과 실무자들의 올바 른 철학, 관점, 역량을 키울 수 있을 것이다. $\mathrm{KOICA}$ 에서 국내 자원봉사단체 및 센터들과 파트 너십을 맺어 활동가 및 실무자 연수도 사업의 한 부분으로 기획한다면 우리나라의 봉사활동 분야 발전에 있어 큰 변화와 반향을 일으키리라 본다. 활동가 및 실무자들 자체의 역량 강화와 변화는 국내외 자원봉사활동 수준을 보다 제고시킬 수 있는 중요한 기반이 될 수 있는 것이다. 많은 자원봉사단체와 센터, 기업들이 해외봉사활동을 기획-운영하는데 있어서 관점과 태도가 변화되면 해외봉사활동에 있어서도 다르게 접근할 것이기 때문이다.

\section{2. 프로그램 (program)}

\section{가. 현지 사람들 주도의 프로그램 개발}

저개발국은 아직 공동체를 통해 많은 문제를 해결하고 있다. 그러나 개발의 바람이 불어 외부와의 소통이 많아지고 청년들이 외지로 떠나는 등 우리가 1960,1970 년대 경제성장 과정에 서 겪었던 일들을 겪고 있다. 공동체가 쉽게 파괴되거나 해체되지 않도록 현지 공동체를 강화하 는 방향의 프로그램을 어떻게 만들어 나갈 것인지, 현지 사람들이 주도적으로 프로그램을 개발하기 위한 과정과 절차는 무엇이고, 누가 도와줄 수 있는지, 어떤 기술과 정보가 필요한지에 대한 질문을 가지고 접근할 필요가 있다. 
현장 사람들이 주도적으로 프로그램 개발을 하도록 하기 위해서는 앞서 언급했듯이 현지 사람들의 성장을 돕는 다양한 시도들이 필요하다. 또한 라오스 지역의 푸딘댕 청소년센터 사례 와 같이 운영되거나, 네팔 지역의 네코스 사례와 같이 지속적인 도움을 줄 수 있는 사람(가령, 은퇴자)이 필요하다. 무엇보다 이런 도움을 주는 데에 있어서 현지인 중심의 사고와 함께 사람을 성장시킨다는 관점과 철학을 가진 사람이 있어야 가능하다. 한국의 봉사활동단체 및 센터들과의 파트너십을 구축함으로써 이러한 유능한 봉사자들을 발굴하고 현장의 요구에 부합하는 지원 노력을 기울일 필요가 있다.

\section{나. 도구 - 현장의 욕구와 언어를 반영한 영향력측정지표, 스토리텔링}

오늘날 전 세계적으로 자원봉사의 사회적 영향력을 측정하기 위한 다양한 노력이 전개되고 있다. $\mathrm{KOICA}$ 역시도 WFK 사업 활동의 성과지표 개발을 위해 지속적으로 노력하고 있다. 그러나 그동안의 경험에 비추어 보았을 때, 영향력 지표 혹은 평가지표가 현장의 언어와 다를 경우 자원봉사자들이 실제 현장에서 지표를 활용하기 어렵다. 현장의 사정을 고려하지 않고 관련 전문가나 실무자 중심으로만 지표가 개발될 시에는 자칫하면 현장과 유리되어 실제 적용이 어려울 뿐만 아니라 도리어 현장에 무리한 잣대를 들이대는 상황이 될 수 있다. 동시에 장기적인 변화를 반영하기 어려운 지표가 될 수도 있다. 따라서 자원봉사자들 자신이 스스로와 자신의 조직, 자신이 참여한 지역사회의 변화를 측정할 수 있도록 쉬운 용어로 질문을 만들 필요가 있다. 실제로 서울시자원봉사센터에서 사회적 영향력 지표를 개발했었는데, 자원봉사자들이 용어를 어려워하여 자원봉사자들과 함께 다시 질문 하나 하나를 수정하여 쉽게 다듬어간 경험이 있다.

그럼에도 불구하고 실제 현장에서는 체계적인 자원봉사자 관리를 위해서 필요한 '지표 (indicator)에 의한 평가를 어려워하는 게 사실이다. 이럴 때는 과감하게 변화스토리로 영향력 을 가늠해볼 수 있다. 훈련된 자원봉사자들이 몇 개의 구조화된 질문들을 가지고 자원봉사자들 을 인터뷰하여 변화스토리를 자연스럽게 끌어낼 수 있다. 가령 서초구자원봉사센터의 경우 자원봉사활동의 다양한 효과를 공유하기 위해 관련 사진과 간단한 스토리 중심의 자원봉사 내용을 '임팩트스토리17)라는 이름으로 엮어 온오프라인으로 발간하고 있는데, 이러한 공유 활 동을 통해 자원봉사자들도 자부심을 갖게 하고, 자원봉사의 가치를 홍보하는 효과도 유발하고 있다.

17) '임팩트스토리' 관련 게시글은 서초구자원봉사센터 홈페이지에서 확인 가능하다: (http://seochov.or.kr/) (접속일: 2017.4.16) 


\section{3. 인프라 및 정책 (Infrastructure \& Policy)}

\section{가. 현지의 자원봉사인프라 지원: 민간자원봉사역량 강화의 과제}

제I장

자원봉사문화를 마련하기 위한 정책적 접근으로 현지인들이 자원봉사의 가치를 홍보하고, 스스로 자원봉사자와 자원을 발굴하고, 프로그램을 만들어 사회 변화를 주도해나가도록 돕는 자원봉사 인프라 지원이 중요하다. 무엇보다 정부의 지원을 이끌어내기도 해야 하지만 그 전에 민간 스스로 필요한 역량을 강화할 수 있도록 도와야 한다. 노하우와 함께 한국에서의 시행착오 를 반복하지 않도록 우리의 경험을 공유할 필요가 있다.

행정자치부의 한국자원봉사협의회를 통한 베트남 자원봉사센터 지도자 역량 강화를 위한 연수는 철저한 준비와 진행으로 베트남 지도자들의 높은 평가를 받았다. 연수과정에서 한국의 제도화를 부러워했지만, 우리나라가 겪은 시행착오를 다시 겪지 않도록 문제점들도 공유했다. 한국의 자원봉사센터들은 대부분 지자체에서 재정 지원을 받고 있기 때문에 그 영향력에서 자유롭지 못하다. 자원봉사의 민간성과 자율성, 독립성이 법 정신에 나와 있음에도 불구하고 지자체의 단체장들이 자원봉사를 정치적으로 활용하는 경우가 종종 나타나고 있다. 민간의 자율성과 전문성, 독립적인 역량이 충분히 성장하기 전에 제도화가 된 탓에 전문적 역량을 충분히 키울 수 없었던 문제가 있었음을 공유하였다.

태국의 경우 쓰나미 대지진 이후 정부와 재단의 지원으로 설립한 Volunteer Spirit Network 라는 단체가 자원봉사센터 역할을 대신하고 있다. 자원봉사와 관련한 급격한 제도화로 인해 많은 문제들이 유발되고 있는 한국의 상황과 달리, 태국은 자원봉사센터의 설립 진행 속도가 매우 더디지만 위에서부터의 급격한 제도화보다는 아래로부터 올라오는 힘으로 민간 주도의 자원봉사센터를 만들겠다는 기본 방향에 맞추어 점진적으로 진행되고 있다.

\section{나. 자원봉사단체/센터 실무 경험자를 인프라 지원 봉사단원으로 파견}

그럼에도 불구하고 짧은 기간에 놀랄 만큼 성장을 이루어 크고 작은 지역문제 해결에 자원봉 사자들이 나설 수 있었던 우리의 경험은 긍정적인 측면이 있으며, 우리의 자원봉사센터와 조직 운영 노하우, 정부와 자원봉사센터의 파트너십 구축 및 운영에 있어서의 시행착오 경험 등은 저개발국의 자원봉사 인프라 설립 지원 시 가치 있는 경험으로 공유될 수 있을 것이다. 인프라 설립 지원을 위해서는 $\mathrm{KOICA} \mathrm{WFK}$ 단원 선발 시, 자원봉사센터와 단체에서 실무 경험을 가진 사람들을 선발하여 현지에 파견하는 방법이 효과적일 것이라 생각한다. 장기간 머물기는 
어렵겠지만 인프라 지원 대상 국가에 이들을 지속적으로 파견하여 현지 실무자들에 대한 교육과 멘토링을 하며 밀착하면 인프라 설립 지원을 효과적으로 할 수 있을 것이다.

\section{4. 한국의 시행착오가 주는 함의: 자원봉사의 가치 훼손 문제, 해외의 사례를 통해 배우는 선순환으로!}

한국의 자원봉사는 그동안 자신과 인간에 대한 이해, 사회 변화를 열망하는 시민들의 자원봉 사 참여가 적지 않은 흐름으로 자리 잡아 왔다. 시간실적에 매이지 않고 태안 기름유출 사고(연 인원 120 만 명)와 세월호 사건 등 도움이 필요한 현장에 달려가 진심으로 활동하는 많은 자원봉 사자들이 있었다. 그러나 한 편으로 지나친 제도화와 시간 수 적립이라는 행정 편의적 유인책으 로 인하여 자원봉사의 가치가 많이 훼손되고 자원봉사의 참여와 문화가 오히려 정체되는 문제가 발생하고 있다. 자원봉사를 통해 사람이 변화되고 성장하며, 좋은 시민이 되도록 하는 자원봉사 의 고유 가치를 회복해야 하는 과제가 있다.

개별 자원봉사활동의 시간을 일일이 관리해주어 과도한 행정력이 투여되고, 자원봉사의 본래 가치가 훼손되는 문제를 해결하고 자원봉사의 가치를 회복하기 위한 자원봉사계의 노력이 진행되고 있다. 해외봉사활동과의 변혁적 파트너십(transformative partnership)에서 도움을 얻고 싶다면, 해외에서 아직 공동체가 파괴되지 않고 있고, 자원봉사가 아직 발달하진 않았지만 성장하는 단계에서 그 가치를 잘 지켜 나가고 있는 사례가 국내에 공유되었으면 한다. 이와 관련한 국가별 사례는 태국, 라오스 등을 비롯해 이미 다양하게 존재한다. 장차 해외봉사활동을 나가게 될 청소년과 대학생들이 자원봉사를 경력이나 시간관리 개념으로 경험한다면 그 피해가 고스란히 다시 해외봉사활동으로 미칠 것이기 때문이다. 청소년 자원봉사와 대학생 자원봉사를 안내하는 자원봉사 관계자, 실무자, 지도자들에게 해외의 사례를 적극 소개하여 우리나라의 자원봉사가 무엇부터 잘못되었는지 스스로 돌아보고 기본부터 다시 시작할 수 있는 자극제가 되었으면 한다. 한국의 자원봉사 문화가 건강하게 자리 잡는다면 이 성과는 해외자원봉사로 이어질 수 있기 때문이다.

한국의 시행착오로부터 자원봉사 활성화를 위한 지나친 제도화의 한계라는 교훈을 얻었다. 이제 자원봉사와 시민사회 형성에 있어 출발단계인 저개발국가에서 공동체를 강화하고 시민사 회의 힘을 키우는 것이 바로 $\mathrm{KOICA}$ 의 역할이 되기를 바란다. 현지 사람들의 애기를 들어보면, 우리나라는 이미 나름대로 엄청난 자원을 지원하고 있음에도 불구하고, 중국이나 일본의 물량공 세에 비해 그 영향력이 작아 보인다. '사람'을 키우고 성장시키는 투자로 전략적인 접근을 한다 면 그 영향력이 보다 커질 거라고 생각한다. 시혜적인 개발보다 현지 주민들이 스스로 성장하고 
조직화하여 문제 해결력을 키워 갈 수 있도록, 보다 장기적인 관점으로 사람에 투자하여 시민사 회 형성에 도움이 주는 것이 $\mathrm{KOICA}$ 의 역할이 되기를 바란다. 


\section{〈참고문헌〉}

이란희·최병대·이원규·우영화·오영수. 2013. 『자원봉사활동의 사회적 영향력 측정지표 개 발 연구』. 서울: 서울시자원봉사센터.

정희선·이원규·이명신·김난희·이은구·김민주. 2016 . 『한국자원봉사의 해 국민운동을 위한 10 대 어젠다(Agenda) 모델사례 발굴 및 보급』. 서울: 행정자치부.

주성수. 2005. 『자원봉사: 이론 제도 정책』. 서울: 도서출판 아르케.

주성수 정희선. 윤영미·이강현. 2014. 『자원봉사활동 실태조사 및 활성화 방안 연구』. 서울:

행정자치부

주성수. 김현옥. 이금룡·정희선·송정안·천희·이란희. 2012. 『자원봉사활동 진흥을 위한 제2차

국가기본계획 최종연구보고서』. 서울: 행정자치부.

한국자원봉사의해 사무국. 2016. '2016-2018 한국자원봉사의 해 가이드북. 서울: 한국자원 봉사의해사무국.

한국자원봉사협의회. 2014. 『2014년 한국자원봉사협의회 글로벌협력사업 결과보고서(한.

베트남 국제개발협력사업)』. 서울: 한국자원봉사협의회.

행정자치부. 2016. 『2016년 자원봉사센터 현황 자료집』. 서울: 행정자치부.

Clary, Gil, Mark Snyder, Robert D. Ridge, John Copeland, Arthur A. Stukas, Julie Haugen and Peter Miene. 1998. "Understanding and Assessing the Motivations of Volunteers: A functional Approach." Journal of Personality and Psychology vol.74(6):1516-30.

1365 자원봉사포털 홈페이지: https://1365.go.kr (접속일: 2017.4.16)

대학사회봉사협의회 홈페이지: http://www.kucss.or.kr/page/profile (접속일: 2017.4.16) 보건복지부 사회복지 자원봉사 인증관리시스템: http://www.vms.or.kr/index.jsp (접속

일: 2017.4.15)

서울시자원봉사센터 홈페이지: http://volunteer.seoul.go.kr/news/notice/view/986?

keyword=\&searchField=\&page=8 (접속일: 2017.4.5)

서울시자원봉사센터 블로그: http://svc1365.tistory.com/969 (접속일: 2017.4.16)

서초구자원봉사센터 홈페이지: http://seochov.or.kr/ (접속일: 2017.4.16)

여성가족부 두볼(Dovol) 홈페이지: http://dovol.youth.go.kr (접속일: 2017.4.15) 
자원봉사이음 홈페이지: https://www.volunteereum.org/ethics) (접속일: 2017.4.14)

통계청 국가지표체계 사이트: http://www.index.go.kr (접속일: 2017.4.16)

한국중앙자원봉사센터 블로그: http://vc1365.tistory.com/653) (접속일: 2017.4.16)

한국자원봉사협의회 홈페이지: http://vkorea.or.kr (접속일: 2017.4.14)

한국자원봉사센터협회 홈페이지: http://www.kfvc.or.kr/ (접속일: 2017.4.14)

UNV 홈페이지: https://www.unv.org/about-unv (접속일: 2017.4.15)

ODA WATCH 뉴스레터 83호(2013.11.5.): http://www.odawatch.net/?mid=articlesth\& page=35\&document_srl=38421（접속일: 2017.4.15） 